\title{
Religious Fundamentalism in Eight Muslim-Majority Countries: Reconceptualization and Assessment
}

Mansoor Moaddel

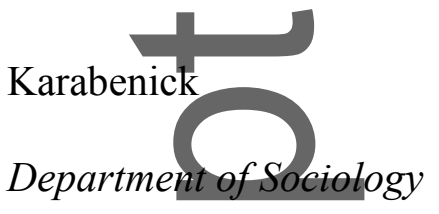

Stuart A.

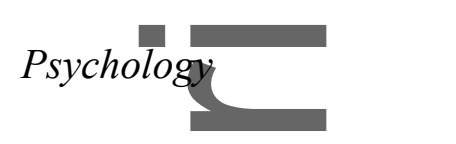

Combined Program in Education and

University of Maryland-College Park

University of

Michigan

Abstract: To capture the common features of diverse fundamentalist movements, overcome etymological variability, and assess predictors, religious fundamentalism is conceptualized as a set of beliefs about and attitudes toward religion, expressed in a disciplinarian deity, literalism, exelusivity, and intolerance. Evidence from representative samples of over 23,000 adults in Egypt, Iraq, Jordan, Lebanon, Pakistan, Saudi Arabia, Tunisia, and Turkey, supports the conclusion that fundamentalism is stronger in countries where religious liberty is lower, religion less fractionalized, state structure less fragmented, regulation of religion greater, and the national context less globalized. Among individuals within countries, fundamentalism is linked to religiosity, confidence in religious institutions, belief in religious modernity, belief in conspiracies, xenophobia, fatalism, weaker liberal values, trust in family and friends, reliance on less diverse information sources, lower socioeconomic status, and membership in ethnic majority, or dominant religion/sect. We discuss implications of these findings for understanding fundamentalism and the need for further research.

Keywords: Fundamentalism, Islam, Christianity, Sunni, Shia, Muslim-majority countries Acknowledgments: Comments by Mark Chaves and anonymous reviewers for JSSR are gratefully acknowledged. This paper is part of a larger collaborative comparative cross-

This is the author manuscript accepted for publication and has undergone full peer review but has not been through the copyediting, typesetting, pagination and proofreading process, which may lead to differences between this version and the Version of Record. Please cite this article as doi: $\underline{10.1111 / \text { jssr. } 12549 .}$.

This article is protected by copyright. All rights reserved. 
national research project, involving Mansoor Moaddel (PI), Arland Thornton (Co-PI), Stuart Karabenick, Linda Young-Demarco, Julie de Jong, and Zeina Mneimneh, and was funded by the Office of Naval Research, Africa command of the U.S. Armed Forces, Jack Shand Research Grant of the Society for the Scientific Study of Religion, Air Force Office of Scientific Research, University of Maryland's Center for Advanced Study of Language, Eastern Michigan University, Göttingen University, and the University of Michigan.

Authors' note: Correspondence should be addressed to Mansoor Moaddel, Department of Sociology, University of Maryland, College Park, MD, 20742-1315, moaddel@umd.edu or 734-657-1128.

\section{Introduction}

The literature on religious fundamentalism has considerably expanded in recent decades. Yet, three major challenges continue to hamper establishing empirical generalization and theoretical abstraction concerning its predictors on the country and individual levels.

First, the movements so characterized vary historically, cross-nationally, and across religions. Examples of such variability are numerous, particularly in contemporary Muslim-majority countries: the Society of the Muslim Brothers in Arab countries, Jama'at Islami in Pakistan, Front Islamique du Salut in Algeria, the Taliban in Afghanistan, the National Islamic Front in the Sudan, Hamas in the Gaza Strip, al-Shabaab in Somalia, and Boko Haram in Nigeria in Sunni Islam; the Fedayeen-e Islam and the followers of Ayatollah Khomeini, the Hezbollah in Lebanon, and the Houthis in Yemen in Shia Islam. Also included are such myriad transnational terror groups as al-Qaeda and the Islamic State in Iraq and the Levant (Ahmad 1964; Mitchell 1969; Sivan 1985; Kepel 1985; Roy 1994; Almond, Appleby, and Sivan 2003).

Complicating the subject is the etymological variability and ambiguity of the term itself. While fundamentalism is traced to some Christian churches in twentieth-century US (Marsden 1980; Wills 1990; Smith 1998) and leading some to argue against its usage in Islam (Esposito 1992), others have argued that the construct is still preferable over the alternatives to identify similar types of movements in Judaism, Islam, and other religious traditions (Martin and Appleby 1991; Moaddel and Karabenick 2013). We propose a conceptualization 
and operational definition of fundamentalism that is multi-dimensional and thus goes beyond the existing approaches in Christianity (Altemeyer 2003; Altemeyer and Hunsberger 2004) and Islam (Moaddel and Karabenick 2008, 2013) and is generalizable to the Abrahamic faiths.

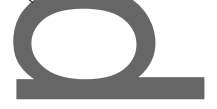

Finally, while scholars have moved beyond single cases to detect general "transnational, transcultural" patterns of religious fundamentalism (Emerson and Hartman 2006:130; Munson 1989; Lawrence 1989; Riesebrodt 1993; Antoun 2008; Almond, Appleby, Sivan 2003), their definitions vary widely and are sometimes constructed in terms that overlook its religious character; that is, fundamentalism is considered (a) a reaction to secularization (Almond, Appleby, Sivan 2003; Kaplan 1992), (b) "an orientation to the modern world" (Antoun 2008:2; Lawrence 1989), (c) "a style of political participation" (Lustick 1988:5), (d) "an urban movement directed primarily against the dissolution of personalistic, patriarchal notions of order" (Riesebrodt 1993:9), and (e) a "hierarchy, patriarchy, discipline, and seclusion" (Barzilai-Nahon and Barzilai 2005:25). Aspects of these definitions are also often conflated with propositional statements concerning the causes of fundamentalism; for example, that fundamentalism is a reaction to modernization (Emerson and Hartman 2006:134; Almond, Sivan, Appleby 1995), or an urban movement to protect a patriarchal order (Riesebrodt 1993).

\section{RECONCEPTUALIZING RELIGIOUS FUNDAMENTALISM}

To overcome these limitations, we propose that fundamentalists, despite their diversity and often irreconcilable differences — such as those found between Christian and Muslim or Shia and Sunni variants — share core orientations toward their own and other's religions (Altemeyer 2003; Altemeyer and Hunsberger 2004; Schwartz and Lindley 2005; Summers 2006; Moaddel and Karabenick 2008, 2013). We conceptualize these core orientations as a distinctive set of beliefs and attitudes that rests on a disciplinarian 
conception of the deity, a literal reading of the scriptures, religious exclusivity, and intolerance. Focusing on the Abrahamic faiths, fundamentalist beliefs and attitudes are distinguishable from the basic tenets of these faiths that the adherents unquestionably accept. These tenets in (Shia and Sunni) Islam, for example, include the belief in the oneness of God, the Prophecy of Muhammad, the Quran as the word God, and the Resurrection and Day of Judgment. In Christianity, they are the belief in the Trinitarian notion of God as Father, Son, and the Holy Spirit, Jesus as the Son of God, and the Virgin Mary. Muslim or Christian fundamentalists certainly believe in the tenets of their own religion. But the belief that their religion is closer to God than other religions, that only Muslims or Christians will go to heaven, that God severely punishes people even though they have engaged in only a minor infraction of religious laws, or that the Quran or the Bible is literally true-all constitute fundamentalist beliefs, because they display distinctive religious orientations rather than asserting specific tenets of either faith.

Fundamentalism also differs from religious conservatism (Belcher et al. 2004). For some, fundamentalism is a subset of conservatism, such as conservative Protestants (Woodberry and Smith 1998), and for others, it is similar to conservatism (Glass and Jacobs 2005; Glass and Nath 2006). However, a clearer conceptualization and more precise measurement of the term, which are necessary for a better understanding of the subject (Woodberry and Smith 1998), require considering fundamentalism and conservatism as distinct phenomena. The latter is primarily concerned with social issues and preserving the norms associated with the religious tradition such as those governing gender relations and communal practices (Grasmick, Wilcox, \& Bird 1990; Smith 1998; Davidman 1991; Hawley 1994), whereas fundamentalism is a distinctive orientation toward one's and others' religion such as adherence to literalism or the belief in the exclusivity or superiority of one's religious community. 
Finally, our conceptualization is deemed preferable to the single-factor conceptions of fundamentalism, primarily those defined solely on text-based inerrancy or intratextuality (e.g., Williamson et al. 2010). The latter exclusively focuses on the scriptures, which is only one facet of religions, Rather, religions are multifaceted, consisting of beliefs in supernatural forces or entities that are codified in the scriptures, embodied in saints and religious leaders, grounded inorganizations, objectified in symbols and sartorial regimes, supported by the communities of the faithful (e.g., the abode of Islam, Christendom), enacted in periodic rituals, and affirmed or referred to in daily conversations. A multidimensional conception of the term that considers these multiple aspects of religion is more stable across individuals and nations than fundamentalism as simply inerrancy. We thus suggest four inter-related components that together constitute fundamentalist orientations. These are beliefs in: (a) a disciplinarian deity - a God who rewards the faithful and punishes in Hell those who fail to follow His instructions; ${ }^{1}$ (b) the inerrancy of the scriptures - the belief in the scriptures as a comprehensive system of universal truth and historical accuracy (e.g., the Chicago Statement ${ }^{1}$ On the face of it, this component applies to only theistic (Abrahamic) religions. Nonetheless, given the fundamentalists' preoccupation with God's retributions - rewards and punishments - a parallel may be established between fundamentalisms in theistic and atheistic religions of the East, like Buddhism, Hinduism, and Jainism. The concept of karma used in varied ways in these religions also revolves on rewards and punishments. We thus propose that in the same way that fundamentalists in the Abrahamic faiths may be concerned over how their actions in this life would bring about God's retributions on the judgment's day, fundamentalists in Eastern religions may also worry about how their misdeeds in this life would result in misfortune in the next and how strict adherence to the teachings of their religions may alleviate such sufferings (BBC 2018; Paine 1997; Faure 2009; Bronkhorst 2011). 
of Biblical Inerrancy 1978), that is superior to science; (c) religious exclusivity — the belief that one's faith is decidedly superior to other faiths and that only the faithful members of one's religion "will enjoy religious rewards and compensators" (Sherkat 2014:24); and (d) religious intolerance ${ }^{2}$ - that the faithful restrict interaction with the followers of other faiths, maintain religious boundaries to keep the faith pure, and limit the rights of other religions. Although the strength of these components may vary among individuals and groups, we propose that they are coterminous with one another and form a single fundamentalism construct.

These features were present in such historically specific forms of fundamentalism as the movements for the rehabilitation of Islam that followed the teachings of Muhammad Ibn Abdul Wahhab (1703-1787) in Arabia and Shah Waliallah (1703-1762) in India. Firmly believing that impurity had crept into the faith, these movements advocated a return to the fundamentals of Islam practiced by the first generation of Muslims, revitalized the notion of the oneness of God to attack the prerogative of the ruling elite, and demanded the formation of an Islamic state in order to protect the purity of the Islamic community from the influence of other cultures, which for Shah Waliallahis meant the folkways and mores of the Hindus, and for the Wahhabis the Ottomans and the Shia (Ahmad 1967; Malik 1980; Hourani 1982; Moaddel 2005).

\footnotetext{
${ }^{2}$ We realize that a multi-dimensional conception of fundamentalism that is too closely related to its historical context (i.e., too concrete and specific) and its components which vary independently of one another may be less stable than a single dimension, as shown in the debate over the church-sect typology (Johnson 1963). The multi-dimensional conception employed here is general and abstract, and its components significantly correlate with one another across the countries (see below).
} 
These religious orientations were revived by Hasan al-Banna (1906-1949), the founder of the Society of the Muslim Brothers in Egypt, and Abul Ala Maududi (1903-1979), the founder of Jamaati Islami in India and Pakistan. For Banna, "the provision of Islam and its teachings are all inclusive, encompassing the affairs of the people in this world and the hereafter.... Islam is a faith and a ritual, a nation... and a nationality, a religion and a state, spirit and deed, holy text and sword" (Mitchell 1969:232). His followers were mobilized to repel what they considered an assault on Islam by secular intellectuals and Christian missionaries (Banna 1978; Lia 1998). Likewise, Maududi’s fundamentalism opposed first the nationalist stand of Muslim theologians in India and later the Pakistan movement for independence, claiming that Muslims were not a national entity but a jamaat governed by the immutable and everlasting divine law. Advancing a literalist exegesis of the Quran, he argued that God was not only the creator, but also the only absolute ruler and legislator for human society (Ahmad 1967). Maududi "did not stand for the political freedom or self-determination of Muslims, butfor the rule of Islam, for a purely Islamic, traditionalist-fundamentalist theocracy" (Ahmad 1967:224).

In Shia Islam, Fedayeen-e Islam, formed in Iran in 1944, was among the sect's first expressions of contemporary fundamentalism. Warning that the society had strayed from the right path, they called for a strict application of the sharia: prohibitions of alcohol, tobacco, opium, films, gambling, and wearing of foreign clothing; enforcement of amputation of hands of thieves and the veiling of women; and eliminating non-Islamic subjects from school curricula. They also demanded restricting the activities of Christians, Jews, and Zoroastrians, and totally banning the Bahais (Abrahamian 1982; Kazemi 2012). Another manifestation of Shia fundamentalism was the Hojjatieh Society (formed in 1953) to combat the spread of the Bahai faith. Like fundamentalist Christians, it displayed a millenarianism penchant, and similar to the Muslim Brothers, it employed a modern organizational and sartorial style (Sadri 
2012). After the Iranian Revolution, the fundamentalists were closely associated with the belief in clerical absolutism and Shia sectarianism. Finally, Osulgarayan (translated as Principalists, Sanandaji 2009) became the nom de guerre of a group of fundamentalist parliamentarians who wanted to distinguish themselves from the reformists.

Despite their differences, these movements were similar in orientations; believing in a total submission to the sharia, Islam as a complete system of truth, and religious exclusivity and intolerance. We measure these orientations, examine the factors linked to cross-national and individual variation in fundamentalism, and discuss the implications of this study for a broader understanding of the subject.

\section{THEORETICAL DEVELOPMENT}

Fundamentalism varies among individuals; some strongly believe in a disciplinarian deity, the inerrancy of the scripture, religious exclusivity, and superiority of their faith over other faiths. Others manifest these beliefs to a lesser extent, and some, such as atheists, not at all. Part of this variation may be due to factors operating at broader sociopolitical and cultural contexts that affect everyone, including globalization, state structures and policies, and the religious profile of the country, and another part related to variation in individual attributes and attitudes. We specify and assess these factors in order to uncover and explain the pattern of variation in religious fundamentalism not only among individuals but also cross-nationally.

\section{Explaining Cross-National Variation in Fundamentalism}

We draw on Moaddel's (2005) episodic-discourse model to explain cross-national variation in religious fundamentalism. Moaddel contrasts modernism and fundamentalism as opposing orientations of Muslim intellectuals toward significant issues. Among these issues are the role of rational reasoning in Islam, secular government, the social status of women, and Western culture. Islamic modernists followed rational exegesis of the Quran, supported constitutional government, reinterpreted religious teachings on gender to favor women, and 
considered Western culture progressive. Islamic fundamentalists, by contrast, followed a literal reading of the Quran, supported the unity of religion and politics in an Islamic government, favored male supremacy and patriarchy, and considered West as culturally decadent.

Moaddel (2005) contends that these diverse orientations were a function of variation in (a) cultural context from pluralistic to monolithic and (b) state intervention in culture from low to high. He then proposes that Muslim intellectual leaders developed modernist orientationsin Egypt and India in the second half of the nineteenth century because they encountered a plurality of discourses advanced by followers of the Enlightenment, Westernizers and think-tanks connected to colonial administration, the missionaries, and the ulama - alt competing for the intellectual control of the society, while state intervention in culture was limited. The rise of fundamentalism in twentieth-century Algeria, Egypt, Iran, and Syria, on the other hand, was a reaction to the monolithic secular discourse imposed from above by the authoritarian ideological state (Moaddel 2005).

Fundamentalism defined as disciplinarian deity, literalism, and religious exclusivity and intolerance reflects a distinctive religious orientation that is different from the definition of the term as orientations toward sociopolitical and cultural issues. The latter are indicators of liberalism-conservatism continuum and considered as predictors of fundamentalism. However, some of the key elements of Moaddel's model are relevant for explaining crossnationalvariation of the phenomenon. First, we propose that pluralistic contexts, inclusive of both secular and religious options for seekers of spirituality, weakens fundamentalism, because this context is likely to offer a richer menu of options to satisfy a wider range of spiritual needs (Montgomery 2003). As a result, fewer of these "spiritual shoppers" (Wuthnow 2005) would be willing to adopt fundamentalism. Furthermore, a pluralistic context exposes the public to a greater number of perspectives on life, security, and 
happiness, reinforcing views concerning the varied ways that metaphysical entities may be worshiped. People are thus less likely to follow a disciplinarian deity and a literal, exclusivist, and intolerant reading of religion (Berger and Luckman 1969). Religious monopolies, on the other hand, may contribute to religious fundamentalism through mobilizing resources, the sanctioning of religious behavior, punishing religious nonobservance, and exploiting sectarian rivalries (Handy 1991; Breault 1989; Blau, Land, and Redding 1992; Blau, Redding, and Land 1993; Ellison \& Sherkat 1995b).

The authoritarian secular state is another aspect of the social context that may shape fundamentalism. Two features of the state are relevant for understanding the relation of religious fundamentalism with regimes. One is the state's regulation of religion.

Fundamentalism may arise as a reaction to such interventions. By launching cultural programs to promote secular institutions, such as fostering national identity as a substitute for religious identity, or instituting laws that run contrary to religious beliefs, a secular state may contribute to the perception among the faithful that their religion is under siege, core values offended, and religious freedom obstructed. This perception of besieged spirituality may activate religious awareness that prompts individuals to grow "hypersensitive even to the slightest hint of theological corruption within their own ranks" (Smith 1998:8), use religious categories to frame issues, and adopt alarmist attitudes and conspiratorial perspectives (Moaddel and Karabenick 2013). While different conceptions of God may coexist in a society (Froese and Bader 2010), the perceived urgency to rise in defense of "His dominion" and combat the all-powerful secular state may popularize among the public an authoritarian conception of deity who handsomely rewards the faithful and severely punishes the unbelievers. As Almond, Appleby, and Sivan (2003:19-20) stated, fundamentalists "fashion their own programs and ideologies in an awkward mimesis of the [state]." 
Fundamentalism may also be influenced by the structure of an authoritarian state. The premise that state structures shape religious outcomes has a long pedigree in the sociology of religion. For example, the success of Protestantism in sixteenth-century Europe is linked to variation in the structure of political sovereignty (Swanson 1967) or state autonomy (Wuthnow 1985). Here, we argue that consequential for the rise of fundamentalism is the extent to which the structure of power relation is unified or fragmented. An authoritarian state under a unified elite would be more effective in imposing a monolithic religion on the subject population, which would limit the available secular or alternative religious options for the seekers of spirituality. An authoritarian state that is controlled by a fragmented elite, on the other hand, tends to experience inter-elite rivalries and acrimonious debates (Moaddel 2016). Such internal disputes would not only diminish the state's ability to impose religious uniformity on society, but also generate the social space that permits the growth of an alternative religious or secular movement (Wuthnow 1989).

In sum, an authoritarian state with a unified structure strengthens and a fragmented structure weakens fundamentalism. The Islamic Republic of Iran and the Kingdom of Saudi Arabia provide contrasting examples. While both regimes are remarkably similar in religious sectarianism, repressiveness, and oil as their sources of revenue, the ruling elite is fragmented in Iran but unifred in Saudi Arabia. The rise of liberalism and religious reformism in Iran (Rajaee 2007; Kamrava 2008; Moaddel 2009) and fundamentalism in Saudi Arabia (Dekmejian 1994, Okruhlik 2002; Champion 2003; Moaddel 2006) appears to correspond to the difference in the structure of power relation between the two regimes.

Finally, globalization may weaken fundamentalism by contributing to the diversification of culture. The development of digital communication technology and the means of mass transportation reduce the constraints of geography on social interactions (Waters 1995), intensifying “worldwide social relations" (Giddens 1990:64) and expanding 
intercontinental networks of economic, political, and cultural interdependence among nations (Keohane and Nye 2000; Frankel 2000; Sassen 2001). These developments globalize economic activities and enhance the diffusion of cultures and civilizational osmoses, facilitating access to diverse information sources, undermining religious monopolies, and thus weakening fundamentalism.

Alternatively, fundamentalism may even be an outcome of globalization by: (a) intensifying the clash of civilizations (Huntington 1996); (b) breaking down the protective shields of small communities as a result of the efforts to eliminate barriers to the world markets, employing similar organizational structures (Stohl 2005), and enforcing a homogeneous cultural pattern (Ritzer 1993), which trigger the feeling of alienation and insecurity (Giddens 1991, Kinnvall 2004); and (c) expanding inequality through the incorporation of the indigenous economies into the global hierarchy of asymmetrical exchange relations of the world capitalist system (Wallerstein 2000).

\section{Individual Variation in Religious Fundamentalism}

To explain cross-national variation in fundamentalism, we focus on religious freedom and fractionalization, state regulation of religion, fragmentation of state authoritarian structure, and globalization. On the individual level, we consider the potential influence of: (a) religiosity, trust in religious institutions, and religious modernity; (b) liberal values; (c) hostility toward outsiders; (d) fatalism; (e) information sources; and (f) demographics.

First, it is evident that without religion, religious fundamentalism may not exist (Peshkin 1988; Ammerman 1987; Kellstedt and Smidt 1991; Lapidus 1992; Lewis 1993; Blaydes and Linzer 2008). Higher religiosity may thus be linked to stronger fundamentalism. Moreover, people with greater confidence in religious institutions are more likely to selfrestrict to such institutions for information and guidance, develop a stronger monolithic view of religion, and are thus more strongly fundamentalist. Finally, individuals who believe that 
religious beliefs foster development—espousing religious modernity—may develop a stronger attitude against secular change, have a more holistic view of religion, and a stronger fundamentalist orientation. Second, fundamentalism is also linked to the conservative and patriarchatvalues as well as submission to religious rule (Lawrence 1989; Kaplan 1992; Riesebrodt1993; Almond, Appleby, Sivan 2003; Antoun 2008; Moaddel 2005). As a corollary of this argument, we propose that individuals who support the liberal values of expressive individualism, gender equality, and secular politics are more likely to express doubt about the truth of religion and less likely to espouse fundamentalism.

Third, as shown by social science research, hostility toward outsiders, or xenophobia, and the belief in conspiracies are linked to rightwing solidarity and religious fundamentalism (Pipes 1996; Euben 1999; Zeidan 2001; Maehr and Karabenick 2005; Inglehart, Moaddel, and Tessler 2006; Choueiri 2010; Bermanis et al. 2010; Koopmans 2014). We further test these hypotheses by assessing their relationships with fundamentalism across eight countries. Likewise, fourth, the belief in obedience to a disciplinarian God and the necessity of surrendering unconditionally to Him may also be stronger among fatalistic individuals, who consider their fate as firmly established and that there is little one can do to change it (Ford 1962; Quinney 1964; Booth 1991; Mercier 1995; Ellerbe 1995; Cohen-Mor 2001; Brink and Mencher 2014).

Fifth, individuals who rely more on family and friends (Ellison 1995; Sherkat 1995) as a source of information concerning religion are less likely to avail themselves of other and more diverse sources, and more likely to espouse stronger fundamentalism. On the other hand, those who rely on diverse sources of information are more likely to be exposed to a variety of perspectives on religion. As a result, they tend to develop a general awareness of the existence of a plurality of belief systems and alternative venues for spiritual satisfaction, and as a consequence, are less likely to espouse religious fundamentalism. 
Finally, among demographics, social class, ethnic and religious identity, urban-rural residence may all be linked to fundamentalism. We argue that higher education and income are likely to weaken fundamentalism; education is said to lower cognitive barriers to enlightenment. The educated are more skilled in analyzing issues, assessing alternative perspectives, and making sense of the world autonomously than those less educated (Schussman and Soule 2005; Krueger and Malečková 2003). They are thus less likely to espouse a literalist, exclusivist, and intolerant view of religion, compared to those with lower levels of education. Also, individuals with higher incomes are less likely to harbor fundamentalist beliefs given their greater access to more diverse cultural perspectives and networks. Lower income individuals, on the other hand, are more likely to support fundamentalism (Blaydes and Linzer 2008; Mehmet 1990; Ayubi 1991; Almond, Appleby, Sivan 2003; Gaskins, Golder, and Siegel 2013). Experiencing a higher level of status insecurity (Weber 1964; Caudill 1963; Weller 1965; Shapiro 1978; Coreno 2002), they are more likely to support the communitarianism of religious fundamentalism (Davis and Robinson 2006).

Inequality in terms of ethnicity and religion or religious sect may also have ramifications for fundamentalism. Parallel to the view that relates prejudice by the members of the dominant ethnic group to their perception of threat from other groups (Blumer 1958; Quillian 1995; Bobo and Hutchings 1996), we assess whether members of the dominant ethnic group are also more strongly fundamentalist than are ethnic minorities. Likewise, we expect that fundamentalism to be higher among members of the dominant religion or religious sect because of their claimed ownership of religion and the perception that religious minorities have deviated from the true path and therefore pose a threat to their religion. Fundamentalism among religious minorities, on the other hand, should be weaker, because 
taking a more moderate religious stand would be accommodating toward the dominant religion and thus reduces religious tensions.

People living in rural areas, with limited access to a more diversified religious environment, may display stronger fundamentalism than those in urban areas. Finally, to rule out the possibility of spurious functions of employment, age, gender, and marital status, we statistically control for these variables.

\section{METHOD}

\section{Sample and Survey Procedure}

Using a multi-stage probability sampling design, face-to-face interviews were conducted of a nationally representative sample of 3,143 adult (age 18+) Egyptians, 3,000 Iraqis, 3,008 Jordanians, 3,034 Lebanese, 3,523 Pakistanis, 1,635 Saudis, 3,070 Tunisians, and 3,019 Turkish in 2011-2016. They add up to over 23,000 completed interviews, representing four hundred million or $26 \%$ of the 1.6 billion world Muslim populations in 2010. ${ }^{3}$ Egypt and Lebanon have sizable Christian populations. A team of investigators developed the questionnaire in collaboration with researchers from the eight countries. ${ }^{4}$ To ensure consistency of meaning across the countries, the questionnaire was translated from English into Arabic, Kurdish, Pashto, Urdu, and Turkish, back translated into English by someone who had not seen the original version, and compared with the original English version. Table 1 shows the sample size, fieldwork date, response rate, and the organization that carried out the survey in each country, and Table 2 provides the respondents' demographics.

\section{Table 1 about here}

\footnotetext{
${ }^{3}$ See http://www.prb.org/Publications/Articles/2011/muslim-population-growth.aspx.

${ }^{4}$ For a copy of the data and the questionnaire, see https://mevs.org/data/surveysummary/1004.
} 


\section{Table 2 about here}

\section{Measurement}

\section{Religious Fundamentalism}

Adhering to the stipulation that a multidimensional conception of fundamentalism more effectively captures the diverse manner in which the subject may be manifested vis-àvis sundry aspects of religion, we operationalized the four components in terms of a series of items that were intended to grasp the multiple meanings linked to each of the components: deity, inerrancy, exclusivity, and intolerance. Initially, our research team developed a total of 25 items with a Likert-scale response format (coded as "strongly agree" $=4$, "agree" $=3$, "disagree" $=2$, and "strongly disagree" =1). Muslim respondents were asked about the Quran, Islam, and Muslims, while Christian respondents about the Bible, Christianity, and Christians. Although we were not allowed to use some of the items in Egypt, no more than one of the excluded items in Egypt, identified with * below, was in the same component, with the remaining items deemed sufficient to provide stable estimates of each component.

Six items measured the beliefs and attitudes that are manifested by a disciplinarian deity. These revolve on God's rewards in heaven, (fear of) punishment, and Satan's scheme. Four items measuring inerrancy (or literalism) highlighted the belief in the comprehensiveness and accuracy of the religious truth and its superiority over man-made laws and science. There were also three reversal items that modified these claims. The measures of exclusivity included four items - stressing that only one's faith is truthful and comprehensive, and only through which salvation is attainable - and one reversal. Finally, five items measured intolerance of other faiths and criticism of one's religion and two reversals.

After incorporating input from researchers in five of the eight countries (where surveys first conducted in 2011), the 25 items were extensively pretested in these countries in 
2010. We then conducted a series of exploratory (EFA) and confirmatory (CFA) factor analyses of the items related to each of the four components to arrive at four sets of four items (a total of 16 items). We examined these sets to construct a single scale with the desired goal of creating a balanced contribution of the four components. EFAs determined that each set of fouritems combining the samples from all countries yielded a single factor for each component with Eigenvalues $>1$ (accounting for $\%$ of the variance) as follows: Deity $=2.12$ $(53 \%)$, Inerraney $=1.61(40 \%)$, Exclusivity $=1.78(45 \%)$, and Intolerance $=1.89(47 \%)$. The four items in each component were then averaged to yield means across the entire sample: Deity $=3.39$, Inerrancy $=3.41$, Exclusivity $=3.35$, Intolerance $=2.60$. An EFA of the four component means yielded a single factor with Eigenvalue $>1(2.50)$ that explained $62.58 \%$ of the varianee.

Wealso assessed whether the entire 16 items would provide a reliable scale. Internal consistency estimates (Cronbach $\alpha$ ) across all countries combined including Egypt with all but the excluded items $=.82$, and using all items when excluding Egypt $=.86$. A further reliability check conducted at the item level for each country resulted in $\alpha$ levels that were also in the acceptable range: Tunisia $=.88$, Lebanon $=.88$, Iraq $=.84$, Turkey $=.80$, Saudi Arabia $=.75$, Jordan $=.74$, Pakistan $=.72$, and Egypt $=.65$. We then averaged the four components to create a single fundamentalism score with the intended balance of the four items for each component, which are as follows (the excluded items are reported in the footnotes):

$$
\text { Deity }^{5}
$$

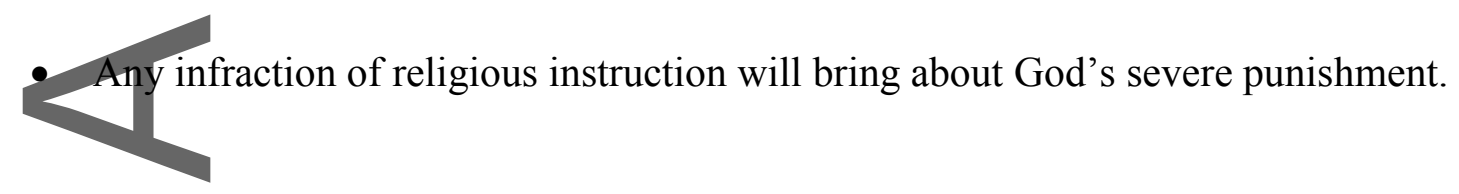

\footnotetext{
${ }^{5}$ The excluded items were: (1) "Allah requires his slaves to repent (tobbah), and (2) "Allah is the source of everything good."
} 
- Only the fear of God keeps people on the right path.*

- Satan is behind any attempt to undermine the belief in God.

- People stay on the right path only because they expect to be rewarded in heaven. Inerrancy $^{6}$

- The Quran (Bible) is true from beginning to end.

- The Quran (Bible) has correctly predicted all the major events in human history.*

- In the presence of the Quran (Bible), there is no need for man-made laws.

- Whenever there is a conflict between religion and science, religion is always right. Exclusivity $^{7}$

- Only Islam (Christianity) provides comprehensive truth about God.

- Only Islam (Christianity) gives a complete and unfailing guide to human salvation.

- Only Muslims (Christians) are going to heaven.

- Islam (Christianity) is the only true religion.*

Intolerance $^{8}$

\footnotetext{
${ }^{6}$ The excluded items were three reversals: (1) The Quran's [Bible's (for Christian respondents)] description of past historical events is not always accurate; (2) The Quran [the Bible (for Christian respondents)] contains general facts, but some of its stories need to be interpreted; (3) Different interpretations of the Quran [the Bible (for Christian respondents)] are equally valid. The first two questions were disallowed in Egypt. In other countries, the first question was negatively linked to fundamentalism, but the other two proved to be conceptually vague.

${ }^{7}$ The excluded item was a reversal question: "All religions are equally acceptable to Allah."
} 
- Our children should not be allowed to learn about other religions.

- The followers of other religions should not have the same rights as mine.

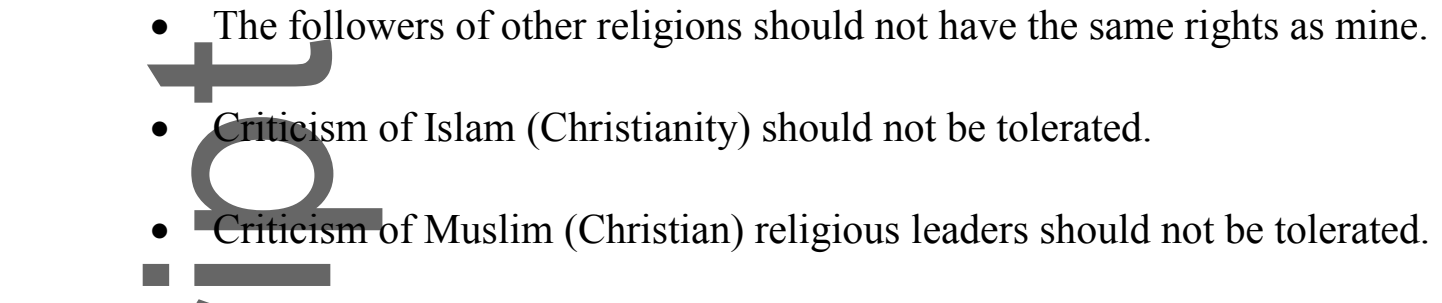

\section{Predictors of Fundamentalism: National Context}

Religious pluralism

Two indicators measured this construct: (a) a religious-liberty index as an average of religious freedom ( 1 =high, $7=$ low $)$ and religious persecution ( $1=$ low, $10=$ high $)$ provided by The Association for Religion Data Archives (ARDA). ${ }^{9}$ This average is recoded so that higher value indicates more religious liberty; and (b) a religious-fractionalization index constructed from the distribution of the sample data by religion/sect that is reported in Table 2, using this formula:

\section{Religious Fractionalization Index $=1-\sum p_{i}^{2}$}

$p_{i}$ is the proportion of religion or sect $i$ in the sample. Higher values indicate greater religious diversity. ${ }^{10}$

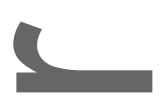

${ }^{8}$ The excluded items were one direct measure-Non-Muslims [Non-Christians (for Christian respondents)] should be prohibited from practicing their religion in (Study Site Country) and two reversal questions (1) The followers of all religions should have equal rights to practice their religion in (Study Site Country), and (2) Non-Muslims [Non-Christians (for Christian respondents)] should be free to build their places of worship in (Study Site

Country).

${ }^{9}$ Roger Finke, Christopher Bader, and Andrew Whitehead, www.thearda.com/internationalData/.

${ }^{10}$ Adopted from the Herfindahl ethnic concentration formula (cited in Posner 2004:849). 


\section{RELIGIOUS FUNDAMENTALISM}

\section{State Structure Fragmentation}

We constructed a fragmentation ratio as the square root of a measure of fractionalized elite $^{11}$ divided by political and civil liberties index. ${ }^{12}$

$$
\text { Fragmentation Ratio }=\frac{\sqrt{\text { Fractionalized Elite }}}{\text { political rights \& civil liberties index }}
$$

\section{State intervention in religion}

A government-regulation-of-religion index $(\mathrm{GRRI})^{13}$ was available for 2003-2008 (averaged) and ranges between 0 (no regulation) and 10 (high regulation).

\section{Globalization}

We used two measures of globalization. One is economic globalization ${ }^{14}$ as an average of standardized measures of International trade - the sum of import and export as percentage of GDP — and Foreign capital penetration (FCP). FCP is measured as:

$$
F C P=\frac{\text { Foreign Direct Investment }}{\sqrt{(\text { Domestic Capital Penetration } * \text { Labor })}}
$$

\section{Internet penetration}

\footnotetext{
${ }^{11}$ http://fundforpeace.org/fsi/data/

${ }^{12}$ https://www.freedomhouse.org/report-types/freedom-world\#.vi6jtcvf9u1.

${ }^{13}$ See http://www.thearda.com.

${ }^{14}$ For GDP, see http://data.worldbank.org/indicator/ne.trd.gnfs.zs; for different measure to construct FCIP, see http://data.worldbank.org/indicator/bx.klt.dinv.wd.gd.zs, http://data.worldbank.org/indicator/bx.klt.dinv.cd.wd, http://data.worldbank.org/indicator/sl.tlf.totl.in, http://data.worldbank.org/indicator/ne.gdi.totl.cd; and for the Internet, see http://data.worldbank.org/indicator/it.net.user.p2.
} 
This was measured as the percentage of the population that had access to the Internet. To make these measures more stable, the three-year average of the data on trade, foreign capital penetration, and Internet access were constructed where data were available for 2009$11,2010-12$, and 2012-14, depending on whether the country survey was completed in 2011, 2013 , or 2016, respectively.

\section{Predictors of Fundamentalism: Individual Level Variables \\ Religiosity index}

This index was constructed by averaging three variables: (a) frequency of prayerranging from (1) never, (2) once a year, (2) once or twice a month, (3) once or twice a week, (4) once a day, (5) two to four times a day to (6) five times daily; (b) self-described as religious-ranging from 1 , not at all religious, to 10 , very religious; and (c) the importance of God in life, ranging from none (1) to utmost important (10). ${ }^{15}$

\section{Confidence in religious institutions}

This construct was measured by one survey question: "Please tell me whether you have (4) a great deal of confidence in religious institutions, (3) quite a lot of confidence, (2) not very much confidence, or (1) none at all?"

\section{Religious modernity index}

This index was constructed as the average of responses to three questions about the belief that religious beliefs foster development: "Would it make your country (1) a lot less developed, (2) less developed, (3) more developed, or (4) a lot more developed, if (a) faith in Allah increases, (b) the influence of religion on politics increases, and (c) the belief in the truth of the Quran [Bible (for Christians)] increases?"

\section{Conspiracy}

\footnotetext{
${ }^{15}$ Mosque attendance is excluded from this index, because the measure carries gender bias; across these countries, women are often discouraged attending mosques.
} 
One question probed respondents about whether they "(4) strongly agree, (3) agree,

(2) disagree, or (1) strongly disagree that there are conspiracies against Muslims (or Christians for Christian respondents).”

\section{Xenophobia}

This index was the average of responses to a series of questions on whether respondents would like to have as neighbors French, British, Americans, Iranians, Kuwaitis in Iraq survey/Indians in Pakistan/Iraqis in other countries, Turkish in Iraq and Saudi Arabia/Saudis in other countries, Jordanians in Iraq/Afghanis in Pakistan/Pakistanis in Saudi Arabia/Syrians in other countries. The responses were coded as 2 for those mentioning "would not like" and 1 for those mentioning "would like" to have them as neighbors.

\section{Fatalism}

Respondents_were asked to choose a number between 1 and 10, where 1 = "people shape their fate themselves" and 10 "everything in life is determined by fate."

\section{Liberalism}

A liberalism index was created by averaging four components of the construct: Expressive-individualism index was the average of three indicators: basis for marriage, a woman's right to dress as she wishes, and child qualities. Response to the basis for marriage was coded as 4 for love and 1 for parental approval, Woman's right to dress was coded as follows in response to the question: "Do you (4) strongly agree, (3) agree, (2) disagree, or (1) strongly disagree that it is up to a woman to dress as she wishes?" For child qualities, respondents were asked to select five from a list of 10 favorable qualities for children to have. Those who selected "independence" or "imagination" were coded as "1", and those who did not select "religious faith" or "obedience" were also coded as " 1 " $(0=$ otherwise $)$. This average was adjusted to range between 1 and 4 . 
A gender-equality index was constructed by averaging responses to: "Do you (1) strongly agree, (2) agree, (3) disagree, or (4) strongly disagree that: (a) "It is acceptable for a man to have more than one wife," (b) “A wife must always obey her husband," (c) "Men make better political leaders," (d) "University education is more important for boys," and (e) "When jobs are scarce, men should have more rights to a job." This index varies between 1 and 4.

Secular politicians measured the support for secular politicians in contrast to those who are religious. It averaged three indicators: "Do you (1) strongly agree, (2) agree, (3) disagree, or (4) strongly disagree that: (a) It would be better for your country if more people with strong religious beliefs held public office; (b) Religious leaders should not interfere in politics?" The answers to this question were recoded so that higher values indicated stronger agreement.

A secular politics index was constructed by averaging responses to three questions as follows. "Do you (4) strongly agree, (3) agree, (2) disagree, or (1) strongly disagree that your country would be a better place if religion and politics were separated." "Would it be (1) very good, (2) fairly good, (3) fairly bad, or (4) very bad for your country to have an Islamic government [Christian government for Christian respondents], where religious authorities have absolute power." And "Is it (1) very important, (2) important, (3) somewhat important, (4) least important, or (5) not at all important for a good government to implement only the sharia (for Muslims) or the laws inspired only by Christian values (for Christians)?" Answers to this question were adjusted to range between 1 and 4 . The average of the four components made a liberalism index, where higher values indicated stronger liberal orientations and weaker conservatism.

\section{Sources of information}


Two indices assessed respondents' sources of information. One was the extent to which the respondents trusted family or friends as sources of information about religion, consisting of the average of responses to two questions: "How much do you trust what (a) family members or (b) friends tell you about the role of religion in politics: (4) a great deal, (3) some, (2) not very much, or (1) none at all?" The second, a plurality-of-informationsources index, was based on averaging how much respondents rely on (a) the radio, (b) foreign (satellite) TV, (c) newspapers, (d) the Internet, and (e) Mobile as a source of information, ranging from (1) not at all, (2) not very much, (3) some, to (4) a great deal.

\section{Demographics}

A socioeconomic-status index was created by averaging education coded in nine categories ranging from no formal education (1) to university degree (9), and household income coded as (1) for the lowest decile and (10) for the highest. ${ }^{16}$ Employment, gender, marital status and rural area, were included as dummy variables; employed (=1, $0=$ otherwise), male ( $=1,0=$ female), and married ( $=1,0=$ otherwise), and Age as reported by respondents.

Coded as rural were those areas with populations of 10,000 or less $(=1)$ and 0 with more than 10,000. For Saudi Arabia, information was available only for the size of town below 500,000 (coded as 1) and more than 500,000 (coded as 0 ). Other dummy variables were also created to specify religious identity: Christian, Druze, Shia, Muslims (sect unidentified) and others. Sunni was used as the reference category; and ethnicity: Arab (versus non-Arab for Lebanon, versus Kurd for Iraq, and versus Berber for Tunisia); Jordanians (versus Palestinians for Jordan); Turk (versus Kurd for Turkey); and Punjabi

\footnotetext{
${ }^{16}$ For Jordan, both education and income had seven categories. In order to retain the maximum number of cases, one indicator was used as a measure of SES, when the other was missing.
} 
(versus Pathani, Sindhi, Kashmiri, and others for Pakistan) were used as the reference categories.

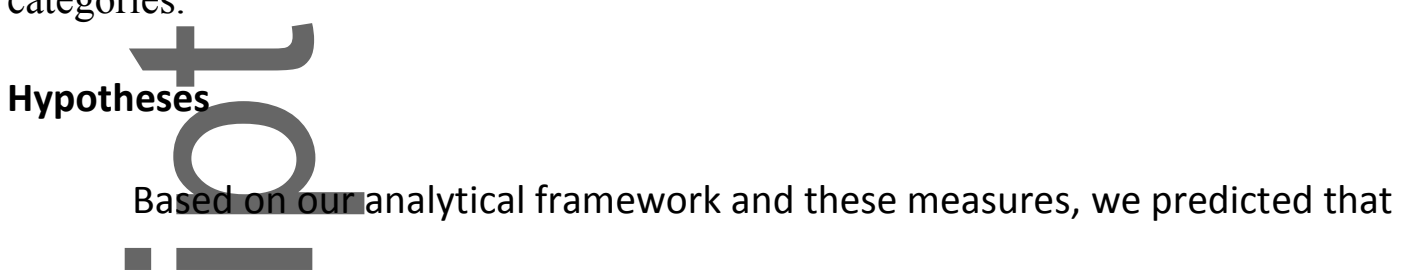

fundamentalism would be stronger in countries characterized by:

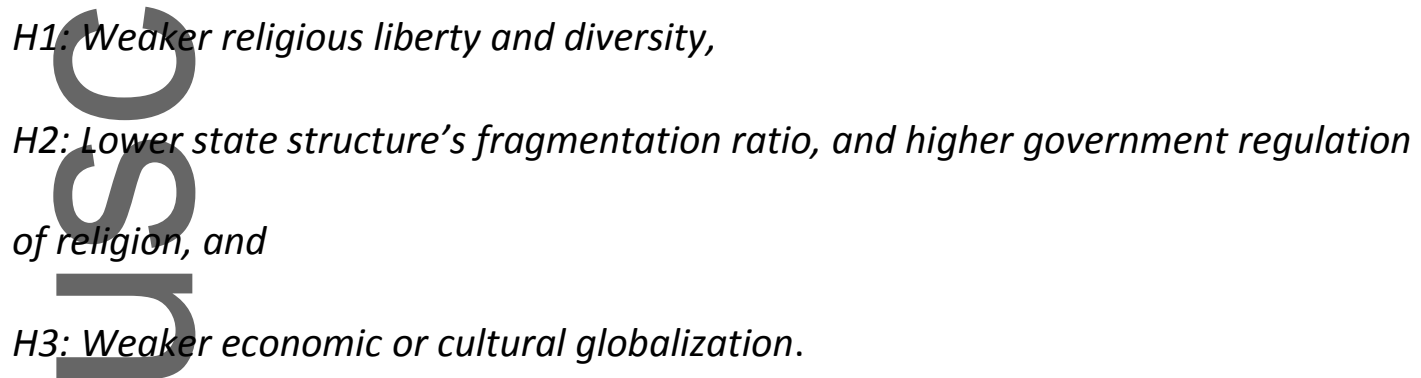

On the individual level, fundamentalism was predicted to be associated with:

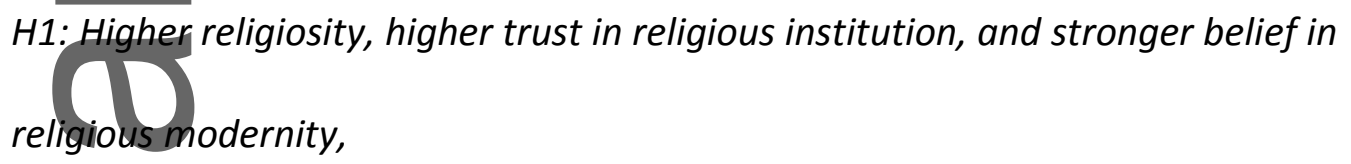

H2: Higher xenophobia, stronger belief in conspiracy, and higher fatalism,

H3: Weaker liberal outlooks (higher conservatism),

H4: Greater trust in family and friends as a source of information about the political role of religion, and lower reliance on diverse information sources, and

H5: Lower socioeconomic status, rural living, and membership in the dominant sect or ethnicity.

\section{Analytic Approach ${ }^{17}$}

ANOVA was used to assess the degree of inter-country variance in fundamentalism, and correlation coefficients to examine the associations between the country level variables and the aggregated level of fundamentalism. Individual level analyses were treated separately

${ }^{17}$ Employing Hierarchical Linear Modeling (HLM) would have been ideal. This was not possible, however, due to the small number of countries (see Raudenbush and Bryk 1992). 
for each country, using Ordinary Least Squares (OLS) regression models to estimate the relationships between individual characteristics and fundamentalism. We employed hierarchical regression to provide additional information about the contribution of different sets of variables to fundamentalism. The absence of some of the variables in several countries precluded conducting a regression analysis using pooled data across all countries.

\section{RESULTS}

\section{Between-Country Analysis}

As shown in Table 3, the level of fundamentalism is high (Mean $=3.21$ on a 1 to 4-pt. scale) summed across all countries. Results of a one-way ANOVA showed statistically significant variance $\left(F_{7,23245}=793.00, p<.000001\right)$ among the countries, which is not surprising because of the large sample size $(n>23,000)$ and thus the high power to detect small differences. Nevertheless, these differences can be considered substantial according to effect size estimates (Cohen 1977). Since effect sizes for $\eta^{2}$ greater than .14 are considered large, the value of $\eta^{2}=.19$ in the present case provides justification that between-country variance in fundamentalism can be considered statistically relatively large over and above the statistical significance that is a function of the very high power. Post-hoc Scheffé pairedcomparison significance tests (at $p<.0001$ ) were conducted to determine which countries differed. These are indicated by means with different superscripts in Table 3. Accordingly, fundamentalism was highest in Egypt and Pakistan, followed by Saudi Arabia, then Iraq and Jordan, and successively lower, respectively, in Tunisia, Turkey, and finally lowest in Lebanon.

\section{Table 3 about here}

Table 4 presents the measures of the country level constructs - religious pluralism, the state's structure and intervention, and globalization. The table also shows the correlations between these measures and the countries' mean level of fundamentalism. 


\section{Pluralistic versus monolithic religious context}

The two variables measuring the extent to which the religious context is monolithic or pluralistic-religious-liberty index and religious-fractionalization index — are both negatively connected to fundamentalism ( $r=-.62$ and -.65 , respectively). These linkages thus support our interpretation that religious diversity and religious liberty provide favorable conditions for individuals to freely pursue their religious preferences and therefore weaken overall fundamentalism on the national level.

\section{Fragmentation of state structure and regulation of religion}

Fragmentation ratio is also negatively linked to fundamentalism $(r=-.66)$. It indicates elite rivalries, which tend to generate the space for the rise of discursive diversity within society and thus weakening of fundamentalism. Government regulation of religion index, on the other hand, is positively linked to fundamentalism $(r=.81)$, supporting our hypothesis that the more the government intervenes in religion, the higher the likelihood of the rise of religious fundamentalism.

\section{Globalization}

Both economic globalization and Internet penetration are negatively linked to fundamentalism $(r=-.55$, and -.52 , respectively). These findings run contrary to the notion that globalization fosters fundamentalism. Globalization effect on fundamentalism, however, appears to be weaker than that of religious diversity, state structure and regulation of religion

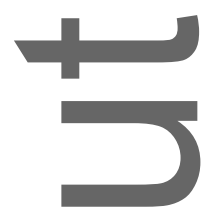

\section{Table 4 about here}

\section{Individual LevelAnalysis}

Table 5 presents descriptive statistics for individual-level variables. Tables 6 to 10 provide results of hierarchical linear regression models (standardized regression estimates $\beta$ ), which begin with a baseline of demographics (Model 1 - Table 6), then successively the 
variance and increased variance accounted for by adding categories of variables designated as religious and ethnic identity (Model 2 - Table 7), religion (Model 3 - Table 8), perceptions and values (Model 4 - Table 9) and sources of information (Model 5 - Table 10). In view of the large number of variables, we tested the models for possible multicolinearity, which was found to be negligible. Most of the variables had variance inflation factors (VIF) less than 2.0 and none exceeding or even close to 5.0 above which there is reason for concern. Taking the models in turn, demographics alone accounted for between 2\% (Iraq) and 10\% (Turkey) of the variance (Model 1). Religious and ethnic minorities accounted for between .6\% (Egypt) and $21 \%$ (KSA) additional variance, after controlling for demographics (model 2), religion variables for another 4\% (Jordan) and 26\% (Lebanon) after controlling for demographics and religious/ethnic minorities (model 3), and perception and values further add between 3\% (Saudi Arabia) and 14\% (Tunisia) to the variance (Model 4), and finally, sources of information add between .1\% (Tunisia) and 3\% (Saudi Arabia), controlling for all other variable sets, all of which are statistically significant increases (Model 5). It should be noted of course that the increases depend on the order in which the variables are entered. All variables combined accounted for between 13\% (Egypt) and 51\% (Lebanon) of the total variance. Although regression estimates vary across models, a function of which variables are in the model, since most estimates are relatively stable and have similar levels of statistical significance, we focus on the final model (Model 5) to discuss the results.

\section{Tables 5-9 about here}

\section{Demographics}

Most notably, fundamentalism is lower for those with higher socioeconomic status, which is consistent across the eight countries. The strength of this relationship, however, varies between countries, from the standardized regression magnitudes of -.126 in Tunisia to -.035 in Lebanon. The link between rural residence and fundamentalism is less consistent 
across the eight countries. People living in rural areas are significantly more fundamentalist than those in urban areas in Egypt, Turkey, and Lebanon $(\beta=.086, .049$, and .102, respectively); but the opposite is the case in Pakistan and Iraq ( $\beta=-.044$ and -.042 , respectively). There is no urban-rural difference in Tunisia or Jordan. Data for Saudi Arabia were available only for the size of towns between those below and over populations of 500,000 . In this case, our analysis shows that people residing in areas with less than 500,000 were more strongly fundamentalist than those residing in areas with populations greater than $500,000(\beta=.310)$. It should be noted that SES and residence results are independent effects since each controls for the other regression estimate and can be considered additive. In other words, especially high levels of fundamentalism were present for persons residing in rural areas who in addition have lower SES.

\section{Religious and ethnic identity}

As we hypothesized, members of religious minorities were consistently less fundamentalist than those in the majority. Minority Shia were less fundamentalist compared to Sunnis in Pakistan, especially in Saudi Arabia, Iraq, Turkey (mostly Alavi Shia), and Lebanon $(\widehat{\beta}=-.038,-.561,-.115,-.037$, and -.160 , respectively), Druze and other religious minorities to Sunnis in Lebanon $(\beta=-.108$ and -.119 , respectively), and Christians compared to Sunnis in Pakistan, Jordan, and Lebanon ( $\beta=-.084,-.154$, and -.111, respectively). There was no significant difference between Sunni Muslims and Christians in Egypt. When only demographics and religion variables (Tables 7 \& 8) are controlled, Christians were less fundamentalist than Sunni Muslims in Egypt. Those who identified themselves as only Muslim were less fundamentalist in $\operatorname{Iraq}(\beta=-.233)$, although more so in Turkey $(\beta=.051)$, but not significantly different from Sunnis in Pakistan and Lebanon. Those identified with much smaller groups or no religious identity were less fundamentalist in Pakistan and Lebanon $(\beta=-.133,-.109$, respectively). 
Fundamentalism is lower among members of ethnic minorities and than those in the majority, but about the same in only two cases. In Pakistan, fundamentalism is weaker among Sindhis, Pathans, and Others than Punjabis $(\beta=-.076,-.050$, and -.100 , respectively), but not significantly different between Punjabis and Kashmiris. Less fundamentalist were also Berbers and others in Tunisia and others in Lebanon than Arabs $(\beta=-.054,-.039$, and -.032, respectively), Palestinians than Jordanians in Jordan $(\beta=-.059)$, and Kurds than Turks in Turkey $(\beta=-.036)$. But Iraqi Kurds were not significantly different from Iraqi Arabs. To explain the two exceptional cases, we postulate that where ethnic minorities are predominantly concentrated in a region of the country and enjoy substantial autonomy from the central government-like Iraqi Kurds or Pakistani Kashmiris - they exhibit no significant difference in fundamentalism with those in ethnic majority. On the other hand, ethnic minorities are less fundamentalist, where they are relatively more dispersed among, and thus interact more often with, the ethnic majority (e.g., Berbers in Tunisia, Sindhis, Pathans, and Others in Pakistan, Others in Lebanon, Palestinians in Jordan, Kurds in Turkey). This area, however, requires further empirical research.

\section{Religion}

Except in Egypt where religiosity has no significant link to fundamentalism, all other religious-related variables are related to fundamentalism. ${ }^{18}$ Religiosity is positively linked to fundamentalism in the other seven countries ( $\beta$ s between .051 for Jordan and .231 for Lebanon), and to trust in religious institutions across all the countries ( $\beta$ s between .032 for

\footnotetext{
${ }^{18}$ One reason for a lack of significant relationship between religiosity and fundamentalism among Egyptians is that these variables have low variability. The standard deviations for religiosity and fundamentalism were .83 and .33 , respectively, both lowest across the eight countries, while the mean fundamentalism was highest and religiosity was the second highest among Egyptians (Tables 3 and 5).
} 
Pakistan and .133 for Tunisia). These findings confirmed similar results from other contexts reported in the literature (e.g., Peshkin 1988; Ammerman 1987; Kellstedt and Smidt 1991; Blaydes and Linzer 2008; Moaddel and Karabenick 2008, 2013). Finally, the belief in religious modernity is significantly linked to fundamentalism across six countries where data on this construct were available ( $\beta$ s between .080 for Egypt and .286 for Lebanon), supporting the connection between the belief that religious beliefs foster development and fundamentalism. This finding suggests that, while fundamentalism may be a reaction to secular modernity (Antoun 2008; Lawrence 1989; Kaplan 1992; Riesebrodt 1993; Almond, Appleby, Sivan 2003), it is not against development, reflecting adherence to religious modernity. As Iranian Muslim intellectual Shariati (1969:23; Hanson 1983) stated, "Europe abandoned religion and made progress, [while] we abandoned religion and went backward." This linkage may also explain why fundamentalism in such contexts as Pakistan under General Zia al-Haqq or Turkey under Recep Tayyip Erdoğan (Talbot 1998; Hussain 1999; Mohiuddin 2007; Gumuscu and Sert 2009) displayed strong support for economic development. Altogether, the robustness of these three predictors across the countries supports the view that this multifactor measure of religion, as conceived here, is an important contributor to the study of religious fundamentalism.

\section{Perceptions and values}

The perception that there are conspiracies against Muslims is positively linked to fundamentalism in every country except Tunisia ( $\beta$ s are between .054 in Turkey and .292 in Iraq). In Tunisia, the size of the correlation coefficient between the belief in conspiracy and fundamentalism is much smaller than the size of its coefficient with liberalism $(r=.082$ versus -.126, respectively, both significant). In all other countries, by contrast, the size of the correlation coefficient between the belief in conspiracy and fundamentalism is either larger than the size of its coefficient with liberalism or close to it. As a result, the link between the 
belief in conspiracy and fundamentalism is insignificance when liberalism index is in the regression equation but significant when it is removed from the equation. Xenophobia is positively linked to fundamentalism in five of the seven countries: Pakistan, Egypt, Jordan, Tunisia, and Lebanon $(\beta=.033, .037, .082, .114$, and .096 , respectively). When religiosity, trust in religious institutions, and liberalism index are removed, its link with fundamentalism is significant in Turkey. Among Iraqis, on the other hand, the question of xenophobia is a bit complicated. Because of intense inter-ethnic and sectarian rivalries between Kurds, Shia, and Sunnis, attitudes toward neighboring countries vary considerably across these three groups (for example, Shia have stronger favorable attitudes toward Iran and Kuwait than either Kurds or Sunnis). Thus, the measure is not as stable as it is in other countries and may not be appropriate to use for Iraq. Questions related to xenophobia were not permitted in Saudi Arabia.

Suspicion of outsiders, as measured by the belief in conspiracies and xenophobia, when considered in conjunction with membership in the dominant religion, indicate the significance of sectarian rivalries in shaping fundamentalism. This finding is not only consistent with the literature (Handy 1991; Breault 1989; Blau, Land, and Redding 1992; Blau, Redding, and Land 1993), but also points to a connection between religious fundamentalism and national chauvinism. Fatalism is consistently and positively linked to fundamentalism across all countries ( $\beta$ s are between .039 for Turkey and .173 in Tunisia). As expected, the liberalism index is markedly inversely linked to fundamentalism across all of the countries, from -.150 in KSA and Iraq to -.365 in Turkey. Alternatively, conservatism is positively linked to fundamentalism.

\section{Sources of information}

Regression estimates showed that fundamentalism is positively linked to trusting family and friends on they tell respondents about the role of religion in politics among 
Pakistanis, Egyptians, Saudis, and Lebanese $(\beta=.032, .070, .115$, and .057 , respectively), but not significantly among Iraqis. This relationship is consistent with findings in the literature on the role of family in shaping people's religious preferences (Ellison 1995). This question was not included in the surveys in the other three countries. Reliance on the plurality of information sources, on the other hand, is consistently negatively linked to fundamentalism across all the countries ( $\beta$ s range between -.162 for Saudi Arabia and -.035 for Turkey), except among Iraqis, where this relationship is positive $(\beta=.057)$. We postulate that the intensification of sectarian rivalries in Iraq might have contributed to the sectarianism of the media - where each group preferred to relay on their sectarian sources of information. As a result, reliance on these sources tended to reinforce, rather than weakening, fundamentalism.

In sum, our analysis at the individual level show that a higher level of fundamentalism is linked to: (a) religion in different ways - religiosity, confidence in religious institutions, and religious modernity; (b) stronger xenophobia and beliefs in conspiracy; (c) higher fatalism and weaker liberal outlooks; (d) a higher trust in family and friends as information sources about religion and less reliance on diverse sources of information; and (e) lower socioeconomic status and membership in ethnic majority, dominant religion or sect.

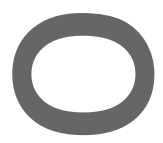

Table 10 about here

\section{DISCUSSION AND CONCLUSIONS}

This study was designed to advance the social-scientific study of fundamentalism in several respects. First, to address the challenges to the study of the subject posed by (a) the diversity of fundamentalist movements, (b) the controversy over the concept in the Islamic context, and (e) the variability of its operational definitions in the literature, we conceptualized the term as a set of core beliefs about and attitudes toward religion that rested on a disciplinarian conception of the deity, literalism, religious exclusivity and intolerance. Our conceptualization thus captures the common features underpinning the diversity of 
fundamentalist movements in Christianity and Islam. Whether Shia, Sunni, or Christian fundamentalists, they are more likely to adhere to a disciplinarian deity, believe in the literal truth of the scriptures, espouse an exclusivist view of their religious community, and be intolerant of other religions than people who are not. Our analyses of the data from crossnationally comparable representative samples of respondents in Egypt, Iraq, Jordan, Lebanon, Pakistan, Saudi Arabia, Tunisia, and Turkey supported combining these components to form a single fundamentalism scale. A stable yardstick was thus created to compare fundamentalism across religions, religious sects, and nations.

Second, our analysis showed that aggregate fundamentalism was higher in countries where religious liberty or diversity was more restricted, state regulation of religion greater and authoritarian structure less fragmented, and the national context less globalized. Third, on the micro (individual) level, our analysis also indicated that fundamentalism was stronger among individuals who were of a lower socioeconomic status, members of the dominant religion/sect or ethnic majority, more religious, expressing greater confidence in religious institutions, and stronger believers in religious modernity, less liberal (more conservative), stronger believers in conspiracy, more xenophobic, more fatalistic, more trusting of what family and friends tell them about political role of religion, and relying less on diverse sources of information. The minor exceptions to this general pattern were noted, explained, and considered not a serious deviation from this general pattern.

These findings have ramifications for our understanding of fundamentalism on a higher level of empirical generalization and theoretical abstraction than in the existing literature. First, given our cross-sectional data it would be hard to assess the extent to which fundamentalism is a reaction to changes in each of the seven countries that would warrant causal conclusions, such as responses to changes in socioeconomic status or state intervention, for example. Its cross-national variation, however, provides suggestive 
consistent evidence. Generally, fundamentalism on the macro (country) level is higher where freedom to engage in religion is restricted by (a) state structure and policies, and (b) religious monopoly. It is weakened under the conditions of (a) religious liberty, and (b) cultural diversity provided by globalization. On this level, the key variables related to cross-national variation in aggregate fundamentalism revolve on religious unfreedom and monopoly. On the (micro) individual level, we showed that fundamentalism does not appear to be a reaction to modernity per se. In fact, it is strongly linked to a religious conception of modernity qua development, where religious belief is believed to foster development. On this level, however, although fundamentalism has multiple determinants, its strength relates to religion (religiosity, religious modernity, and trust in religious institutions), personal inefficacy (subjectively [fatalism] and objectively [lower socioeconomic status]), illiberal values, outgroup hostility (xenophobia, conspiracy, religious or ethnic domination), and monolithic information source.

As noted above, we fully recognize that while we have advanced possible explanations of the subject, our cross-sectional data precludes definitive causal claims, which would require collecting data at multiple points in time. Even though fundamentalism is treated statistically as a dependent variable, we do not rule out reciprocal causations or that the direction of causality to be just the opposite of what our model has specified. From our perspective, the specified factors are statistical predictors of fundamentalism and that our model is one way of interpreting the pattern of relationship between the variables. Nonetheless, these societal conditions and personal characteristics that are linked to the measure of the construct as orientations toward religion rather than religious beliefs themselves advance the social-scientific study of fundamentalism in an empirically more generalizable and theoretically more abstract manner. 
With that foundation, we suggest that future research move in several directions. One is to apply the analytical framework employed here to study Jewish fundamentalism and examine whether the same or similar set of variables predict fundamentalist orientations among Jews, particularly in Israel. We also suggest applying our measurement of the construct to examine fundamentalism in such atheistic or nontheistic religions as Brahmanism, Buddhism, and Jainism. For sure, the disciplinarian conception of the deity, one of the components of fundamentalism, may not be directly applicable to Eastern religions. However, given that our indicators of this component revolve on the notion of reward and punishment from God, a similar set of measures may be formulated that focuses on a retributive conception of karma that stresses on the severity of punishment in the next life from misdeed in this life. Finally, another line of research is to go beyond religion and develop parallel measures that tap into fundamentalism in other belief systems, including secular fundamentalism such as the literalism, group-centrism, and intolerance displayed among the followers of different secular ideologies. This line of research may produce the necessary empirical evidence in order to construct a more general conception of fundamentalism that includes both religious and secular variants. We hope that the present research provided the foundation for a broader understanding of the concept and its assessment. 


\section{REFERENCES}

Ahmad, Aziz. 1964. Studies in Islamic culture in the Indian environment. Oxford: Oxford University Press.

-1967. Islamic modernism in India and Pakistan: 1857-1964. London: Oxford University Press

Almond, Gabriel A., Emmanuel Sivan, and R. Scott Appleby. 1995. "Fundamentalism: genus and species." Pp. 399-424 in Fundamentalisms comprehended. Chicago: University of Chicago Press.

Almond, Gabriel A., R. Scott Appleby, and Emmanuel Sivan. 2003. Strong religion: the rise of fundamentalism around the world. Chicago: The University of Chicago Press.

Altemeyer, Bob R. 2003. "Why do religious fundamentalists tend to be prejudiced?" The International Journal for the Psychology of Religion. 13(1): 17-28.

Altemeyer, Bob, and Bruce Hunsberger. 2004. “A revised religious fundamentalism scale: the short and sweet of it." International Journal for the Psychology of Religion. $14(1): 47-54$

Ammerman, Nancy T. 1987. Bible believers: fundamentalists in the modern world. New Brunswick, NJ: Rutgers University Press.

Antoun, Richard T. 2008, Understanding fundamentalism: Christian, Islamic, and Jewish movements, Lanham, MD: Rowman \& Littlefield.

Ayubi, Nazih. 1991. Political Islam: religion and politics in the Arab world. London: Routledge.

Barzilai-Nahon, Karine, and Gad Barzilai. 2005. "Cultured technology: the Internet and religious fundamentalism.” The Information Society 21(1):25-40. 
Banna, Hasan al-. 1978. Five tracts of hasan al-banna (1906-1949). Translated by Charles Wendell. Berkeley: University of California Press.

BBC, 2018. “Karma,” http://www.bbc.co.uk/religion/religions/buddhism/beliefs/karma.shtml (retrieved April 14).

Belcher, John R., Donald Fandetti, and Danny Cole. 2004. "Is Christian religious conservatism compatible with the liberal social welfare state?" Social Work, 49, 2 (April): 269-276.

Berger, Peter L., and T. Luckmann. 1969. "Sociology of religion and sociology of knowledge." Pp. 61-73 in Sociology of religion, edited by Roland Robertson. New York: Penguin Books.

Bermanis, Shai, Daphna Canetti-Nisim, and Ami Pedahzur. 2010. "religious fundamentalism and the extreme right-wing camp in Israel," Patterns of Prejudice, 38: 2, 159-176.

Blau, Judith R., Kenneth C. Land, and Kent Redding. 1992. "The expansion of religious affiliation." Social Science Research 21(4):329-352.

Blau, Judith R., Kent Redding, and Kenneth C. Land. 1993. "Ethnocultural cleavages and the growth of church membership in the United States, 1860-1930.” Sociological Forum 8(4): 609-637.

Blau, Peter and Joseph Schwartz. 1984. Crosscutting social circles. New York: Academic Press.

Blaydes, Lisa and Drew A. Linzer. 2008. “The political economy of women's support for fundamentalist Islam.” World Politics 60(4): 576-609.

Blumer, Herbert. 1958. "Race prejudice as a sense of group position." Pacific Sociological Review 1(1):3-7.

Booth, Leo 1991. When god becomes an addiction. New York: Penguin. 
Breault, Kevin D. 1989. "New evidence on religious pluralism, urbanism and religious participation." American Sociological Review 54(6):1056-1059.

Brink, Judy and Joan Mencher. 2014. Mixed blessing: gender and religious fundamentalism cross-culturally. Routledge.

Bronkhorst, Johannes. 2011. Buddhism in the shadow of Brahmanism. Leiden: Brill Caudill, Harry M. 1963. Night comes to the Cumberlands. Boston: Little and Brown.

Champion, Daryl. 2003. The paradoxical kingdom: Saudi Arabia and the momentum of reform. New York: Columbia University Press.

Chicago Statement on Biblical Inerrancy. 1978. From the Dallas theological seminary archives, repository of ICBI archives.

Choueiri, Youssef M. 2010. islamic fundamentalism: the story of Islamist movements. New York: Continuum International Publishing Group.

Cohen-Mor, Dalya 2001. A matter of fate: the concept of fate in the Arab world as reflected in modern Arabic literature. Oxford: Oxford University Press.

Cohen, Jacob. 1977. Statistical power analysis for the behavioral sciences.

Routledge.

Coreno, Thaddeus. 2002. "Fundamentalism as a class culture." Sociology of Religion $63(3): 335-360$

Davidman, Lynn. 1991. Tradition in a rootless world: women turn to Orthodox Judaism. Berkeley: University of California Press.

Davis, Nancy. J. and Robert V. Robinson, 2006. The egalitarian face of Islamic orthodoxy: Isupport for Islamic law and economic justice in seven Muslim-majority Nations. American Sociological Review 71(2):167-190.

Dekmejian, Hrair. 1994. "The rise of political Islamism in Saudi Arabia.” Middle East Journal 48:627-43. 
Eisenstadt, Shmuel N. 2000. "Multiple modernities.” Daedalus 129(1):1-29.

Ellerbe, Helen 1995. The dark side of Christian history. San Rafael: Morning Star Books.

Ellison, Christopher G. 1995. "Rational choice explanations of individual religious behavior: notes on the problem of social embeddedness." Journal for the Scientific Study of Religion 34(1):89-97.

Emerson, Michael O. and Hartman, David. 2006. "The rise of religious fundamentalism." Annual Review of Sociology 32(August):127-144.

Esposito, John L. 1992. The Islamic threat: myth or reality? Oxford: Oxford University Press.

Euben, Roxanne. 1999. Enemy in the mirror: Islamic fundamentalism and the limits of modern nationalism. Princeton: Princeton University Press.

Faure, Bernard. 2009. Unmasking Buddhism. Chichester, West Sussex, UK: WileyBlackwell.

Ford, Thomas R. 1962. "The passing of provincialism.” Pp. 9-34 in The southern appalachian region: a survey, edited by T. R. Ford. Lexington, KY: University of Kentucky Press.

Frankel, Jeffery. 2000. "Globalization of the economy.” Pp. 45-71 in Governance in a globalizing world, edited by J. S. Nye Jr. and J. D. Donahue. Washington, DC: Brookings Institution Press.

Froese, Paul and Christopher D. Bader. 2010. America's four Gods. Oxford: Oxford University Press.

Gaskins, Ben, Matt Golder, David A. Siegel. 2013. "Religious participation and economic conservatism." American Journal of Political Science 57(4):823-840.

Ghazali al-, Zainab. 2006. Return of the Pharaoh. Leicestershire: The Islamic Foundation. 
Giddens, Anthony. 1990. The consequences of modernity. Stanford: Stanford University

Press.

Giddens, Anthony. 1991. Modernity and self-identity: self and society in the late modern age. Stanford. Stanford University Press.

Glass, Jennifer and Jerry Jacobs. 2005. "Childhood religious conservatism and adult attainment among black and white women.” Social Forces, 84, 1 (September): 555579.

Glass, Jennifer and Leda E. Nath. 2006. “Religious conservatism and women’s market behavior following marriage and childbirth.” Journal of Marriage and Family, 68 (August): 611-629.

Grasmick,Harold G., Linda Patterson Wilcox, and Sharon R. Bird. 1990. "The effects of religious fundamentalism and religiosity on preference for traditional family norms." Sociological Inquiry, 60, 4 (November):352-369.

Gumuscu, Sebnem and Deniz Sert. 2009. "The power of the devout bourgeoisie: the case of the Justice and Development Party in Turkey." Middle Eastern Studies 45(6):953:968.

Handy, Robert T. 1991. Undermined establishment. Princeton, NJ: Princeton University<smiles>[R16][AsH2]</smiles>

Hanson, Brad. 1983. "The 'westoxciation” of Iran: depictions and reactions of Behrangi, al-e Ahmad, and Shariati." International Journal of Middle East Studies 15(1):1-23.

Hawley, John S. ed. 1994. Fundamentalism and gender. Oxford, UK: Oxford University

Press.

Hefner, Robert W. 1998. "Multiple modernities: Christianity, Islam, and Hinduism in a globalizing age." Annual Review of Anthropology 27:83-104.

Huntington, Samuel P. 1996. The clash of civilizations and the remaking of world order. New York: Simon and Schuster. 
Hussain, Ishrat. 1999. Pakistan: the economy of an elitist state. Karachi: Oxford University Press.

Inglehart, Ronald, Mansoor Moaddel and Mark Tessler. 2006. "Xenophobia and in-group solidarity in iraq: a natural experiment on the impact of insecurity." Perspective on Politics 4(3):495-505.

Johnson, Benton 1963. "On church and sect," American Sociological Review. 28: 539-549. Kamrava, Mehran. 2008. Iran's intellectual revolution. Cambridge: Cambridge University Press.

Kaplan, Lawrence. ed., 1992. Fundamentalism in comparative perspective. Boston: The University of Massachusetts Press.

Kazemi, Farhad. 2012. “Fedā'iān-e Eslām,” Encyclopedia Iranica, vol. IX, Fasc. 5, pp. 470474.

Kellstedt, Lyman, \& Smidt, Corwin. 1991. "Measuring fundamentalism: an analysis of different operational strategies.” Journal for the Scientific Study of Religion $30(3): 259-278$.

Keohane, Robert O. and Joseph S. Nye. 2000. Power and interdependence, 3d ed. Boston: Addison-Wesley.

Kepel, Gilles. 1985. Muslim extremism in Egypt: the prophet and pharaoh. Berkeley: University of California Press.

Khomeini, Ruhollah, 1981. Islam and revolution: writings and declarations of Imam Khomeini. Translated and annotated by H. Algar. Berkeley: Mizan Press.

Kinnvall, Catarina. 2004. "Globalization and religious nationalism: self, identity, and the search for ontological security." Political Psychology 25(5):741-767. 
Koopmans, Ruud. 2014. "Religious fundamentalism and hostility against out-groups: a comparison of Muslims and Christians in Western Europe," Journal of Ethnic and Migration Studies, 41:1, 33-57,

Krueger, Alan B. and Jitka Malečková. 2003. "Education, poverty and terrorism: is there a causal connection?" Journal of Economic Perspectives 17(4):119-144.

Lapidus, IraIM.1992. "The Golden Age: The political concepts of Islam.” The Annals of the American Academy of Political and Social Science 524(1):13-25.

Lawrence, Bruce. B. 1989. Defenders of God: the fundamentalist reach against the modern age. San Francisco: Harper \& Row.

Lewis Bernard. 1993. "Islam and liberal democracy.” Atlantic Monthly February.

Lustick, Ian. S. 1988. For the land and the lord: Jewish fundamentalism in Israel.

Washington, DC: The Council on Foreign Relations.

Maehr, Martin L., and S.A. Karabenick. Editors. 2005. Advances in motivation and achievement. Amsterdam: Elsevier.

Malik, Hafeez. 1980. Sir Sayyid Ahmad Khan and Muslim modernization in India and Pakistan. New York: Columbia University Press.

Marsden, George M. 1980. Fundamentalism and American culture. Oxford: Oxford University Press.

Marty, Martin E. and R. Scott Appleby. 1991. Fundamentalism observed. Chicago: The University of Chicago Press.

Mehmet, Ozay, 1990. islamic identity and development: studies of the Islamic periphery, London: Routledge.

Mercier, Jean L. 1995. "Truth of orthodoxy." Cross Currents 45(1) 68-79.

Mitchell, Richard P. 1993 [1969]. The society of the Muslim brothers. Oxford: Oxford University Press. 
Moaddel, Mansoor. 2005. Islamic modernism, nationalism, and fundamentalism: episode and discourse. Chicago: University of Chicago Press. . 2006. "The Saudi public speaks: religion, gender, and politics," International Journal of Middle East Studies 38(1):79-108. 2009. "The Iranian revolution and its nemesis: the rise of liberal values among Iranians." Comparative Studies of South Asia, Africa, and the Middle East 29(1):126136.

. 2016, "The Saudi religious predicament," Vanguardia dossier (July-September):121124.

Moaddel, Mansoor and Stuart A. Karabenick. 2008. "Religious fundamentalism among young Muslims in Egypt and Saudi Arabia." Social Forces 86(4):1675-1710. 2013. Religious fundamentalism in the Middle East: A Cross-National, Inter-Faith, and Inter-Ethnic Analysis. Leiden, The Netherlands: Brill.

Mohiuddin, Yasmeen Niaz. 2007. Pakistan: a global studies handbook. Santa Barbara: ABCCLIO, Inc.

Montgomery, James D. 2003. "A formalization and test of the religious economies model." American Sociological Review 68(5):782-809.

Munson, Henry, Jr. 1989. Islam and revolution in the Middle East. Yale University Press.

Okruhlik, Gwenn. 2002. "Networks of dissent: Islamism and reform in Saudi Arabia." Current History 651(101):22-28.

Paine, Andrew. 1997. "Religious fundamentalism and legal systems: methods and rationales in the fight to control the political apparatus.” Indiana Journal of Global Legal Studies, 5, 1: 263-296.

Peshkin, Alan. 1988. God's choice: the total world of a fundamentalist Christian school. Chicago: University of Chicago Press. 
Pipes, Daniel. 1996. The hidden hand: the Middle East fears of conspiracy. New York:

Palgrave.

Posner, Daniel N. 2004. "Measuring ethnic fractionalization in Africa." "American Journal of Political Seience." 48(4):849-863.

Quillian, Lincoln. 1995. "Prejudice as a response to perceived group threat: population composition and anti-immigrant and racial prejudice in Europe." American

Sociological Review 60(4):586-611.

Quinney, Richard. 1964. “Political conservatism, alienation, and fatalism: contingencies of social status and religious fundamentalism." Sociometry 27(3):372-381.

Rajaee, Farhang. 2007. Islamism and modernism: the changing discourse in Iran. Austin: University of Texas Press.

Raudenbush, Stephen W. and Anthony S. Bryk. 2002. Hierarchical linear models: applications and data analysis methods. London and New Delhi: Sage Publications.

Reid, Donald Malcolm. 1990. Cairo University and the making of modern Egypt. Cambridge: Cambridge University Press.

Riesebrodt, Martin. 1993. Pious passion: the emergence of modern fundamentalism in the

United States and Iran. Translated by Don Reneau. Berkeley: University of California Press.

Ringer, Fritz. 2004. Max Weber: an intellectual biography. Chicago: University of Chicago

Press.

Ritzer, George. 1993. The McDonaldization of society. Boston: Pine Forge Press.

Robertson, Roland. 1989. "Internationalization and globalization." University center for international studies newsletter: 8-9.

Roy, Olivier. 1994. The failure of political Islam. Cambridge: Harvard University Press. 
Sadri, Mahmoud. 2004 [updated 2012]. "Hojjatiya," Encyclopedia Iranica, vol. XII, Fasc. 4, pp. $426-428$.

Sanandaji, Kaveh-Cyrus. 2009. "The eighth majles elections in the Islamic Republic of Iran: a division in conservative ranks and the politics of moderation," Iranian Studies, 42, 4: $621-648$.

Sassen, Saskia. 2001. The global city. Princeton: Princeton University Press.

Sayyid Qutb. 2000 [1953]. Social justice in Islam. Translated by J. B. Hardie. Islamic Publications International.

Schussman, Alan and Sarah A. Soule. 2005. "Process and protest: accounting for individual protest participation.” Social Forces 84(2):1083-1108.

Schwartz, Jonathan P. and Lori D. Lindley. 2005. "Religious fundamentalism and attachment: prediction of homophobia." International Journal for the Psychology of Religion 15(2):145-157.

Shapiro, Henry D. 1978. Appalachia on our mind. Chapel Hill: University of North Carolina Press.

Shariati, Ali. 1969/1347. Islamshenasi. Mashhad: Tous.

Sherkat, Darren E. 1995. "Embedding religious choices: integrating preferences and social constraints into rational choice theories of religious behavior.” Pp. 65-86 in Assessing rational choice theories of religion, edited by Lawrence Young. New York: Routledge.

.2014. Changing faith: the dynamics and consequences of Americans' shifting religious identities. New York: New York University Press.

Sivan, Emmanuel. 1985. Radical Islam: medieval theology and modern politics. New Haven: Yale University Press.

Smith, Christian. 1998. American evangelicalism: embattled and thriving. Chicago: University of Chicago Press. 
Stark, Rodney, and Roger Finke. 2000. Acts of faith: explaining the human side of religion.

$$
\text { Berkeley: University of California Press. }
$$

Stohl, Cynthia. 2005. “Globalization theory.” Pp. 223-262 in Engaging organizational communication theory and research: multiple perspectives, edited by S. May and D. Mumby. Thousand Oaks: Sage.

Summers, Frank 2006. "Fundamentalism, psychoanalysis, and psychoanalytic theories." Psychoanalytic Review 93(2) 329-353.

Swanson, Guy E. 1967. Religion and regime: a sociological account of the reformation. Ann Arbor: University of Michigan Press.

Talbot, Ian. 1998. Pakistan, a modern history. New York: St. Martin's Press.

Tariq, Malik Mohammad. 2011. "The Rise and impact of Islamic fundamentalism in Pakistan After the Soviet invasion of Afghanistan with special reference to KPK and Balochistan." Balochistan Review 1(24):1-13.

Wallerstein, Immanuel. 2000. The Politics of the world-economy: the states, the movements, and the civilizations. Cambridge: Cambridge University Press.

Waters, Málcolm. 1995. Globalization. London: Routledge.

Weber, Max. 1964. The Sociology of religion. Boston: Beacon.

Weller, JackE. 1965. Yesterday's people. Lexington: University of Kentucky Press.

Williamson, Paul W., Ralph W. Hood Jr, Aneeq Ahmad, Mahmood Sadiq \& Peter C.

Hill. 2010. The intratextual fundamentalism scale: cross-cultural application, validity evidence, and relationship with religious orientation and the Big 5 factor markers. Mental health, religion and culture, 13:7-8, 721-747

Wills, Garry 1990. Under God: religion and politics in America. New York: Simon and Schuster. 
Woodberry, Robert D. and Christian Smith. 1998. "Fundamentalist et al: conservative protestants in America." Annual Review of Sociology. 24: 25056.

Wuthnow, Robert. 1985. "State structures and ideological outcomes." American Sociological Review 50(6):799-821.

Wuthnow, Robert. 2005. America and the challenges of religious diversity. Princeton: Princeton University Press.

Zeidan, David. 2001. "The Islamic fundamentalist view of life as a perennial battle." Middle East Review of International Affairs 5(4):26-53.

Table 1 Data Collection Overview

\begin{tabular}{l|cccc}
\hline & $\begin{array}{c}\text { Sample } \\
\text { Size }\end{array}$ & $\begin{array}{c}\text { Survey } \\
\text { Dates }\end{array}$ & $\begin{array}{c}\text { Response Data Collection Institution } \\
\text { Rate (\%) }\end{array}$ & \begin{tabular}{c} 
or Firm \\
\hline Egypt
\end{tabular} \\
3,143 & June-Aug 2011 & 93 & ERTC, Cairo \\
Iraq & 3,000 & Jan-Feb 2011 & 88 & IIACSS, Baghdad \\
Jordan & 3,008 & Apr-May 2016 & 80 & U of Jordan, Amman \\
Lebanon & 3,034 & Mar-July 2011 & 61 & ICOD \& Am. U., Beirut \\
Pakistan & 3,523 & May-Sept 2011 & 83 & U of Agriculture, Faisalabad \\
KSA & 1,635 & Jan-Feb 2011 & 73 & PARK, Jeddah \\
Tunisia & 3,070 & Mar-May 2013 & 78 & ELKA Consulting, Tunis \\
Turkey & 3,019 & Apr-June 2013 & 62 & FREKANS, Istanbul \\
\hline KSA
\end{tabular}

$\mathrm{KSA}=$ Kingdom of Saudi Arabia

Table 2 Respondents' Demographic Characteristics (\%)

\begin{tabular}{|c|c|c|c|c|c|c|c|c|}
\hline $\begin{array}{c}\text { Sample } \\
\text { characteristics }\end{array}$ & Pakistan & Egypt & KSA & Iraq & Jordan & Lebanon & Tunisia & Turkey \\
\hline Mean age & 35 & 39 & 34 & 36 & 42 & 35 & 44 & 41 \\
\hline Male & 51 & 48 & 50 & 53 & 50 & 59 & 45 & 44 \\
\hline University & 4 & 17 & 17 & 13 & 17 & 28 & 17 & 13 \\
\hline Married & 76 & 82 & 64 & 70 & 74 & 50 & 66 & \\
\hline \multicolumn{9}{|l|}{ Religion: } \\
\hline Sunni & 90.0 & 96 & 92 & 40 & 97 & 23 & 99 & 86 \\
\hline Shi’a & 8.6 & - & 8 & 31 & & 33 & - & 2 \\
\hline Allawi & & & & & & & & 4 \\
\hline Muslim (no sect) & 8 & & - & 29 & & 3 & - & 7 \\
\hline Druze & & & & & & 6 & - & - \\
\hline Christian & 1.4 & 4 & - & $<1$ & 3 & 27 & - & - \\
\hline
\end{tabular}

$\mathrm{KSA}=$ Kingdom of Saudi Arabia

Table 3 Descriptive Statistics of Fundamentalism in the Eight Countries 


\begin{tabular}{c|ccccccccc}
\hline & Egypt & Pakistan & KSA & Iraq & Jordan & Tunisia & Turkey & Lebanon & Total \\
\hline Mean & $3.44^{\mathrm{a}}$ & $3.42^{\mathrm{ab}}$ & $3.39^{\mathrm{b}}$ & $3.27^{\mathrm{c}}$ & $3.26^{\mathrm{c}}$ & $3.18^{\mathrm{d}}$ & $2.97^{\mathrm{e}}$ & $2.80^{\mathrm{f}}$ & 3.21 \\
$\mathrm{SD}$ & .33 & .32 & .41 & .41 & .34 & .46 & .55 & .59 & .49 \\
$\mathrm{~N}$ & 3,142 & 3,523 & 1,506 & 2,991 & 3,008 & 3,065 & 2,994 & 3,024 & 23,253 \\
\hline
\end{tabular}

Note: $F_{7,23245}=793.00, p<.000001 . \eta^{2}=.19$, which is a large effect size $=>.14$ according to Cohen (1977). Post-hoc Scheffé paired comparisons: means with different superscripts are significantly different at $p<.001$. KSA $=$ Kingdom of Saudi Arabia

Table 4 National Aggregate Religious Fundamentalism and Measures of National Context

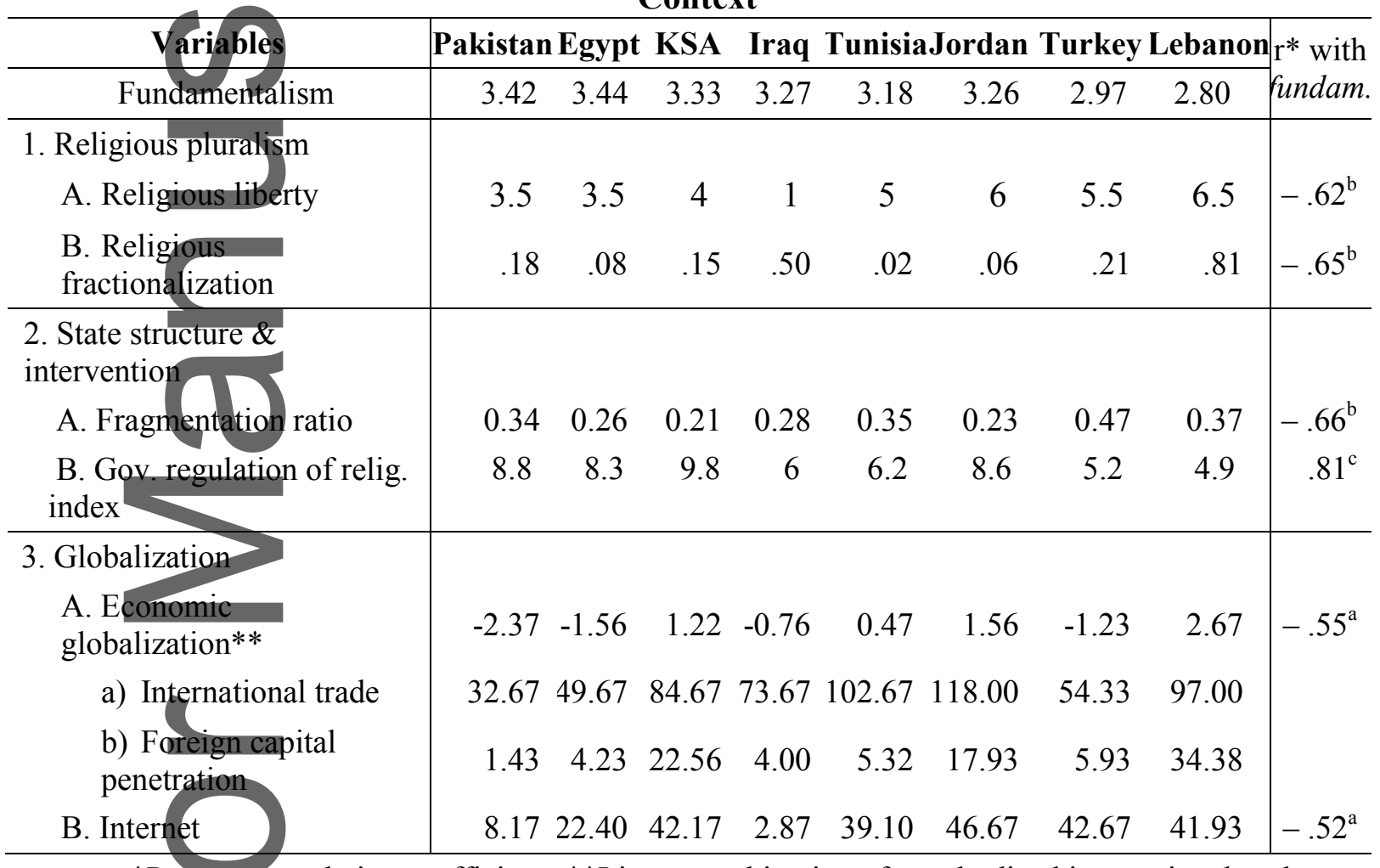

*Pearson correlation coefficients ** Linear combination of standardized international trade and foreign capital penetration

${ }^{\mathrm{a}} p<0.1{ }^{\mathrm{b}} p<.05^{\mathrm{c}} p<.01$. Note: These are all considered large effect sizes according to Cohen (1977).

KSA = Kingdom of Saudi Arabia

Table 5 Aggregate Individual Variable Descriptive Statistics for Each Country: Mean (SD)

\begin{tabular}{c|cccccccc}
\hline $\begin{array}{c}\text { Variable } \\
\text { (Response range) }\end{array}$ & Pakistan & Egypt & KSA & Jordan & Iraq & Tunisia & Turkey Lebanon \\
\hline \multicolumn{7}{c}{ Demographics } \\
\hline Socioeconomic status & 4.01 & 4.40 & 5.61 & 3.10 & 3.62 & 5.24 & 4.07 & 5.87 \\
$(1-10)$ & $(1.58)$ & $(1.96)$ & $(1.63)$ & $(.86)$ & $(1.65)$ & $(1.51)$ & $(1.81)$ & $(1.85)$ \\
\hline Employed & .48 & .44 & .37 & .29 & .43 & .38 & .34 & .61 \\
$(0-1)$ & $(.50)$ & $(.50)$ & $(.48)$ & $(.45)$ & $(.49)$ & $(.49)$ & $(.48)$ & $(.49)$ \\
\hline Male & .51 & .48 & .50 & .50 & .53 & .44 & .44 & .59 \\
$(0-1)$ & $(.50)$ & $(.50)$ & $(.50)$ & $(.50)$ & $(.50)$ & $(.50)$ & $(.50)$ & $(.49)$ \\
\hline Not Married & .21 & .19 & .32 & .21 & .24 & .27 & .21 & .42
\end{tabular}




\begin{tabular}{|c|c|c|c|c|c|c|c|c|}
\hline$(0-1)$ & $(.41)$ & $(.39)$ & $(.47)$ & $(.41)$ & $(.43)$ & $(.45)$ & $(.41)$ & $(.49)$ \\
\hline $\begin{array}{c}\text { Age } \\
(18-80) \\
\end{array}$ & $\begin{array}{c}35 \\
(12.02) \\
\end{array}$ & $\begin{array}{c}39 \\
(14.74) \\
\end{array}$ & $\begin{array}{c}34 \\
(13.39) \\
\end{array}$ & $\begin{array}{c}42 \\
(15.65) \\
\end{array}$ & $\begin{array}{c}36 \\
(13.00) \\
\end{array}$ & $\begin{array}{c}44 \\
(17.03) \\
\end{array}$ & $\begin{array}{c}41 \\
(16.13) \\
\end{array}$ & $\begin{array}{c}35 \\
(12.83) \\
\end{array}$ \\
\hline $\begin{array}{l}\text { Rural } \\
(0-1)\end{array}$ & $\begin{array}{l}.53 \\
(.50)\end{array}$ & $\begin{array}{l}.20 \\
(.40)\end{array}$ & & $\begin{array}{l}.18 \\
(.38)\end{array}$ & $\begin{array}{l}.52 \\
(.50)\end{array}$ & $\begin{array}{l}.29 \\
(.45)\end{array}$ & $\begin{array}{c}.82 \\
(.39)\end{array}$ & $\begin{array}{l}.59 \\
(.49)\end{array}$ \\
\hline \multicolumn{9}{|c|}{ Religion } \\
\hline $\begin{array}{c}\text { Religiosity Index } \\
(0-10)\end{array}$ & $\begin{array}{l}7.13 \\
(.95)\end{array}$ & $\begin{array}{l}7.55 \\
(.83)\end{array}$ & $\begin{array}{c}7.34 \\
(1.01)\end{array}$ & $\begin{array}{l}7.66 \\
(.96) \\
\end{array}$ & $\begin{array}{l}7.48 \\
(.98)\end{array}$ & $\begin{array}{c}7.02 \\
(1.32)\end{array}$ & $\begin{array}{c}7.03 \\
(1.40)\end{array}$ & $\begin{array}{c}6.40 \\
(1.80)\end{array}$ \\
\hline $\begin{array}{l}\text { Confidence in Rel. Inst. } \\
(1-4)\end{array}$ & $\begin{array}{l}2.97 \\
(.81)\end{array}$ & $\begin{array}{l}3.63 \\
(.67) \\
\end{array}$ & $\begin{array}{l}3.32 \\
(.78) \\
\end{array}$ & $\begin{array}{l}3.75 \\
(.60) \\
\end{array}$ & $\begin{array}{l}3.08 \\
(.78) \\
\end{array}$ & $\begin{array}{l}3.57 \\
(.86) \\
\end{array}$ & $\begin{array}{c}2.77 \\
(1.01)\end{array}$ & $\begin{array}{l}2.45 \\
(.90) \\
\end{array}$ \\
\hline $\begin{array}{c}\text { Religious Modernity } \\
(1-4)\end{array}$ & $\begin{array}{l}3.74 \\
(.37) \\
\end{array}$ & $\begin{array}{l}3.39 \\
(.52) \\
\end{array}$ & $\begin{array}{l}3.21 \\
(.56) \\
\end{array}$ & & $\begin{array}{l}3.17 \\
(.57)\end{array}$ & & $\begin{array}{l}2.78 \\
(.65) \\
\end{array}$ & $\begin{array}{l}2.65 \\
(.73)\end{array}$ \\
\hline \multicolumn{9}{|c|}{ Perception \& Values } \\
\hline $\begin{array}{c}\text { Conspiracy against } \\
\text { Muslims } \\
(1-4)\end{array}$ & $\begin{array}{l}3.48 \\
(.65)\end{array}$ & $\begin{array}{l}3.36 \\
(.89)\end{array}$ & $\begin{array}{l}3.22 \\
(.81)\end{array}$ & $(.74)$ & $\begin{array}{c}3.08 \\
(1.00)\end{array}$ & $\begin{array}{l}3.31 \\
(.92)\end{array}$ & $\begin{array}{l}2.86 \\
(.79)\end{array}$ & $\begin{array}{l}2.91 \\
(.98)\end{array}$ \\
\hline $\begin{array}{l}\text { Xenophobia } \\
(1-2)\end{array}$ & $\begin{array}{l}1.66 \\
(.34)\end{array}$ & $\begin{array}{l}1.72 \\
(.30)\end{array}$ & & $\begin{array}{l}1.52 \\
(.35)\end{array}$ & $\begin{array}{l}1.66 \\
(.31)\end{array}$ & $\begin{array}{l}1.42 \\
(.35)\end{array}$ & $\begin{array}{l}1.46 \\
(.45)\end{array}$ & $\begin{array}{l}1.46 \\
.37\end{array}$ \\
\hline $\begin{array}{c}\text { Fatalism } \\
(1-10)\end{array}$ & $\begin{array}{c}6.29 \\
(1.96) \\
\end{array}$ & $\begin{array}{c}7.41 \\
(2.80) \\
\end{array}$ & $\begin{array}{l}5.25 \\
(2.69) \\
\end{array}$ & $\begin{array}{c}7.31 \\
(3.09) \\
\end{array}$ & $\begin{array}{c}6.10 \\
(2.35) \\
\end{array}$ & $\begin{array}{c}7.65 \\
(2.86) \\
\end{array}$ & $\begin{array}{c}5.14 \\
(2.87) \\
\end{array}$ & $\begin{array}{l}5.77 \\
(2.66) \\
\end{array}$ \\
\hline $\begin{array}{l}\text { Liberalism Index } \\
(1-4)\end{array}$ & $\begin{array}{l}1.98 \\
(.45) \\
\end{array}$ & $\begin{array}{l}2.08 \\
(.42) \\
\end{array}$ & $\begin{array}{l}2.24 \\
(.42) \\
\end{array}$ & $\begin{array}{l}2.15 \\
(.40) \\
\end{array}$ & $\begin{array}{l}2.23 \\
(.39) \\
\end{array}$ & $\begin{array}{l}2.48 \\
(.53)\end{array}$ & $\begin{array}{l}2.63 \\
(.48)\end{array}$ & $\begin{array}{l}2.72 \\
(.49) \\
\end{array}$ \\
\hline \multicolumn{9}{|c|}{ Sources of Information } \\
\hline $\begin{array}{c}\text { Family/Friends } \\
(1-4)\end{array}$ & $\begin{array}{l}3.12 \\
(.50)\end{array}$ & $\begin{array}{l}3.21 \\
(.78)\end{array}$ & $\begin{array}{l}3.24 \\
(.70)\end{array}$ & & $\begin{array}{l}3.30 \\
(.58)\end{array}$ & & & $\begin{array}{l}2.99 \\
(.68)\end{array}$ \\
\hline $\begin{array}{l}\text { Plurality of Info Sources } \\
(1-4)\end{array}$ & $\begin{array}{l}2.51 \\
(.53)\end{array}$ & $\begin{array}{l}1.58 \\
(.54)\end{array}$ & $\begin{array}{l}2.50 \\
(.69)\end{array}$ & $\begin{array}{l}1.87 \\
(.66)\end{array}$ & $\begin{array}{l}1.87 \\
(.64)\end{array}$ & $\begin{array}{l}1.94 \\
(.67)\end{array}$ & $\begin{array}{l}1.63 \\
(.62)\end{array}$ & $\begin{array}{l}2.23 \\
(.70)\end{array}$ \\
\hline
\end{tabular}

$\mathrm{KSA}=$ Kingdom of Saudi Arabia

Table 6 Hierarchical Linear Regression Estimates $(\beta)$ Prediction of Fundamentalism - Model

\begin{tabular}{c|cccccccc}
\hline \multicolumn{1}{c|}{ Variable } & Pakistan & Egypt & KSA & Jordan & Iraq & Tunisia & Turkey Lebanon \\
\hline \multicolumn{7}{c}{ Demographics } \\
\hline Socioeconomic status & $-.170^{\mathrm{d}}$ & $-.182^{\mathrm{d}}$ & -.023 & $-.202^{\mathrm{d}}$ & $-.117^{\mathrm{d}}$ & $-.220^{\mathrm{d}}$ & $-.281^{\mathrm{d}}$ & $-.149^{\mathrm{d}}$ \\
Employed & .020 & .018 & -.057 & .005 & -.009 & $-.052^{\mathrm{a}}$ & $-.077^{\mathrm{b}}$ & -.032 \\
Male & -.002 & -.002 & $-.076^{\mathrm{a}}$ & -.004 & .026 & .017 & $.089^{\mathrm{d}}$ & $-.102^{\mathrm{d}}$ \\
Not Married & -.028 & -.024 & -.039 & -.047 & -.047 & $-.074^{\mathrm{b}}$ & -.033 & $-.074^{\mathrm{b}}$ \\
Age & $.128^{\mathrm{d}}$ & -.030 & .042 & $-.059^{\mathrm{b}}$ & .022 & .018 & $-.066^{\mathrm{b}}$ & .020 \\
Rural (smaller town for & $.088^{\mathrm{d}}$ & $.117^{\mathrm{d}}$ & $.248^{\mathrm{d}}$ & -.023 & $-.085^{\mathrm{d}}$ & .009 & $.099^{\mathrm{d}}$ & $.137^{\mathrm{d}}$ \\
KSA) & & & & & & & & \\
\hline F & $52.68^{\mathrm{d}}$ & $25.41^{\mathrm{d}}$ & $21.63^{\mathrm{d}}$ & $21.92^{\mathrm{d}}$ & $10.41^{\mathrm{d}}$ & $32.94^{\mathrm{d}}$ & $45.40^{\mathrm{d}}$ & $30.16^{\mathrm{d}}$ \\
df regression/df residual & $3378 / 6$ & $2775 / 6$ & $1501 / 6$ & $2897 / 6$ & $2488 / 6$ & $2483 / 6$ & $2335 / 6$ & $2432 / 6$ \\
$\mathrm{R}^{2}$ & .086 & .052 & .080 & .043 & .024 & .074 & .104 & .069 \\
\hline
\end{tabular}

${ }^{\mathrm{a}} p<.05 \quad{ }^{\mathrm{b}} p<.01 \quad{ }^{\mathrm{c}} p<.001 \quad{ }^{\mathrm{d}} p<.0001 \quad \mathrm{KSA}=$ Kingdom of Saudi Arabia 
Table 7 Hierarchical Linear Regression Estimates $(\beta)$ Prediction of Fundamentalism - Model 2

\begin{tabular}{|c|c|c|c|c|c|c|c|c|}
\hline Variable & Pakistan & Egypt & KSA & Jordan & Iraq & Tunisia & Turkey & Lebanon \\
\hline \multicolumn{9}{|c|}{ Demographics } \\
\hline Socioeconom & $-.165^{\mathrm{d}}$ & $-.178^{d}$ & -.022 & $-.180^{\mathrm{d}}$ & $-.130^{\mathrm{d}}$ & $-.212^{\mathrm{d}}$ & $-.272^{\mathrm{d}}$ & $-.103^{\mathrm{d}}$ \\
\hline & .036 & .017 & -.025 & .010 & -.002 & $-.051^{\mathrm{a}}$ & $-.065^{\mathrm{b}}$ & -.018 \\
\hline $\mathrm{M}$ & -.010 & -.002 & $-.092^{b}$ & -.010 & .021 & .025 & $.082^{\mathrm{d}}$ & $-.083^{\mathrm{d}}$ \\
\hline Not & -.041 & -.022 & -.053 & -.027 & $-.055^{\mathrm{a}}$ & $-.070^{\mathrm{b}}$ & -.032 & -.028 \\
\hline & $.126^{\mathrm{d}}$ & -.028 & .024 & -.017 & .018 & .024 & $-.070^{\mathrm{b}}$ & .038 \\
\hline Rural (sm & .034 & $.117^{\mathrm{d}}$ & $.195^{\mathrm{d}}$ & -.005 & $-.068^{\mathrm{d}}$ & .012 & $.085^{\mathrm{d}}$ & $.159^{\mathrm{d}}$ \\
\hline \multicolumn{9}{|c|}{ Religious Identity } \\
\hline Shia v & $-.102^{\mathrm{d}}$ & & $-.637^{\mathrm{d}}$ & & $-.050^{\mathrm{a}}$ & & $-.130^{\mathrm{d}}$ & $-.133^{\mathrm{d}}$ \\
\hline Druze & & & & & & & & $-.192^{\mathrm{d}}$ \\
\hline Muslim (Sect unic & -.010 & & & & $-.143^{\mathrm{d}}$ & & $.065^{\mathrm{c}}$ & -.032 \\
\hline vs. Sunni & & & & & & & & \\
\hline Christian vs. & $-.200^{\mathrm{d}}$ & $-.076^{\mathrm{d}}$ & & $-.232^{\mathrm{d}}$ & & & & $-.310^{\mathrm{d}}$ \\
\hline Other vs. Sul & -.242 & & & & . & & -.032 & $-.326^{\mathrm{d}}$ \\
\hline \multicolumn{9}{|c|}{ Ethnic Identity } \\
\hline Sindhi & $-.097^{\mathrm{d}}$ & & & & & & & \\
\hline Pathan vs. P & $.058^{\mathrm{c}}$ & & & & & & & \\
\hline Kashmiri vs. & $.130^{\mathrm{d}}$ & & & & & & & \\
\hline Other vs. Punjab & -.034 & & & & & $-.065^{\mathrm{c}}$ & & $-.054^{b}$ \\
\hline $\begin{array}{r}\text { Kurd/Berber/vs. } \\
\text { Kurd vs. Tu }\end{array}$ & & & & & -.001 & $-.109^{d}$ & -.007 & \\
\hline Palestinian vs. Jo & \multicolumn{8}{|c|}{$-.063^{b}$} \\
\hline & $74.24^{d}$ & $24.30^{\mathrm{d}}$ & $87.54^{\mathrm{d}}$ & $39.32^{\mathrm{d}}$ & $10.87^{\mathrm{d}}$ & $30.21^{\mathrm{d}}$ & $33.94^{\mathrm{d}}$ & $55.92^{\mathrm{d}}$ \\
\hline df regressio & $3370 / 14$ & $2774 / 7$ & $1500 / 7$ & $2895 / 82$ & $2484 / 10$ & $2481 / 8$ & $2331 / 10$ & $2426 / 12$ \\
\hline & .236 & .058 & .290 & .0 .97 & .042 & .089 & .127 & .201 \\
\hline 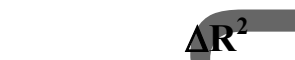 & .150 & $.006^{\mathrm{d}}$ & .210 & .054 & $.017^{\mathrm{d}}$ & .015 & .023 & .132 \\
\hline
\end{tabular}

Table 8 Hierarchical Linear Regression Estimates $(\beta)$ Prediction of Fundamentalism - Model 3

\begin{tabular}{|c|c|c|c|c|c|c|c|c|}
\hline Variable & Pakistan & Egypt & KSA & Jordan & Iraq & Tunisia & Turkey & Lebanon \\
\hline \multicolumn{9}{|c|}{ Demographics } \\
\hline Socioeconomic status & $-.135^{\mathrm{d}}$ & $-.157^{\mathrm{d}}$ & $-.061^{\mathrm{b}}$ & $-.162^{d}$ & $-.092^{\mathrm{d}}$ & $-.200^{\mathrm{d}}$ & $-.160^{\mathrm{d}}$ & $-.084^{\mathrm{d}}$ \\
\hline Employed & .018 & .017 & -.033 & .007 & -.003 & -.031 & $-.052^{\mathrm{b}}$ & -.016 \\
\hline Male & .033 & -.003 & -.031 & .011 & .034 & $.051^{\mathrm{a}}$ & $.064^{\mathrm{b}}$ & -.016 \\
\hline Not Married & -.028 & -.018 & -.031 & -.022 & -.010 & $-.052^{\mathrm{a}}$ & .004 & .024 \\
\hline Age & $.053^{\mathrm{b}}$ & -.027 & .002 & -.037 & .009 & -.009 & $-.056^{\mathrm{b}}$ & .007 \\
\hline
\end{tabular}


RELIGIOUS FUNDAMENTALISM

\begin{tabular}{|c|c|c|c|c|c|c|c|c|}
\hline $\begin{array}{l}\text { Rural (smaller town for } \\
\text { KSA) }\end{array}$ & -.012 & $.087^{\mathrm{d}}$ & $.215^{\mathrm{d}}$ & -.006 & $-.086^{\mathrm{d}}$ & .024 & $.072^{\mathrm{d}}$ & $.124^{\mathrm{d}}$ \\
\hline \multicolumn{9}{|c|}{ Religious Identity } \\
\hline Shia vs. Sunni & $-.074^{\mathrm{d}}$ & & $-.540^{\mathrm{d}}$ & & $-.101^{\mathrm{d}}$ & & $-.058^{\mathrm{c}}$ & $-.165^{\mathrm{d}}$ \\
\hline Druze vs. Sunni & & & & & & & & $-.127^{\mathrm{d}}$ \\
\hline $\begin{array}{l}\text { Muslim (Sect unidentified) } \\
\text { vs. Sunni }\end{array}$ & .005 & & & & $-.200^{\mathrm{d}}$ & & $.067^{\mathrm{d}}$ & $-.033^{\mathrm{a}}$ \\
\hline Christian vs. Sunni & $-.145^{\mathrm{d}}$ & $-.071^{\mathrm{d}}$ & & $-.222^{\mathrm{d}}$ & & & & $-.203^{\mathrm{d}}$ \\
\hline Other vs. Sunni & $-.167^{\mathrm{d}}$ & & & & & & -.010 & $-.152^{\mathrm{d}}$ \\
\hline \multicolumn{9}{|c|}{ Ethnic Identity } \\
\hline Sindhi vs. Punjabi & $-.092^{\mathrm{d}}$ & & & & & & & \\
\hline Pathan vs. Punjabi & .008 & & & & & & & \\
\hline Kashmiri vs. Punjabi & $.046^{\mathrm{b}}$ & & & & & & & \\
\hline Other vs. Punjabi/Arab & $-.107^{\mathrm{d}}$ & & & & & $-.044^{\mathrm{a}}$ & & $-.047^{\mathrm{b}}$ \\
\hline $\begin{array}{c}\text { Kurd/Berber vs. } \\
\text { Arab/Kurd vs. Turk }\end{array}$ & & & & & $-.090^{\mathrm{d}}$ & $-.078^{\mathrm{d}}$ & .00 & \\
\hline Palestinian vs. Jordanian & & & & $-.061^{\mathrm{b}}$ & & & & \\
\hline \multicolumn{9}{|l|}{ 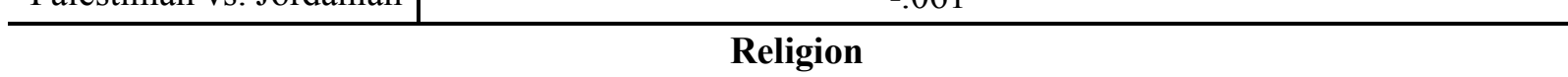 } \\
\hline Religiosity & $.165^{\mathrm{d}}$ & .025 & $.179^{\mathrm{d}}$ & $.098^{\mathrm{d}}$ & $.146^{\mathrm{d}}$ & $.140^{\mathrm{d}}$ & $.135^{\mathrm{d}}$ & $.293^{\mathrm{d}}$ \\
\hline $\begin{array}{l}\text { Trust in Religious } \\
\text { Institutions }\end{array}$ & $.115^{\mathrm{d}}$ & $.070^{\mathrm{d}}$ & $.126^{\mathrm{d}}$ & $.173^{\mathrm{d}}$ & $.153^{\mathrm{d}}$ & $.227^{\mathrm{d}}$ & $.167^{\mathrm{d}}$ & $.090^{\mathrm{d}}$ \\
\hline Religious Modernity Index & $.189^{\mathrm{d}}$ & $.131^{\mathrm{d}}$ & $.181^{\mathrm{d}}$ & & $.274^{\mathrm{d}}$ & & .293 & $.341^{\mathrm{d}}$ \\
\hline $\mathrm{F}$ & $92.37^{\mathrm{d}}$ & $24.60^{\mathrm{d}}$ & $91.86^{\mathrm{d}}$ & $47.31^{\mathrm{d}}$ & $44.77^{\mathrm{d}}$ & $48.11^{\mathrm{d}}$ & $72.95^{\mathrm{d}}$ & $139.67^{\mathrm{d}}$ \\
\hline df regression/df residual & $3367 / 17$ & $2771 / 10$ & $1497 / 10$ & $2893 / 10$ & $2481 / 13$ & $2479 / 10$ & $2328 / 13$ & $2423 / 15$ \\
\hline $\mathrm{R}^{2}$ & .318 & .082 & .380 & .141 & .190 & .163 & .289 & .464 \\
\hline$\Delta \mathrm{R}^{2}$ & $.082^{\mathrm{d}}$ & $.024^{\mathrm{d}}$ & $.090^{\mathrm{d}}$ & $.043^{\mathrm{d}}$ & $.148^{\mathrm{d}}$ & $.074^{\mathrm{d}}$ & $.162^{\mathrm{d}}$ & $.263^{\mathrm{d}}$ \\
\hline
\end{tabular}

${ }^{\mathrm{a}} p<.05 \quad{ }^{\mathrm{b}} p<.01 \quad{ }^{\mathrm{c}} p<.001 \quad{ }^{\mathrm{d}} p<.0001 \quad \mathrm{KSA}=$ Kingdom of Saudi Arabia

Table 9 Hierarchical Linear Regression Estimates ( $\beta$ ) Prediction of Fundamentalism - Model 4

\begin{tabular}{|c|c|c|c|c|c|c|c|c|}
\hline Variable & Pakistan & Egypt & KSA & Jordan & Iraq & Tunisia & Turkey & Lebanon \\
\hline \multicolumn{9}{|c|}{ Demographics } \\
\hline Socioeconomic status & $-.058^{\mathrm{C}}$ & $-.134^{\mathrm{d}}$ & $-.077^{\mathrm{b}}$ & $-.135^{\mathrm{d}}$ & $-.064^{\mathrm{d}}$ & $-.142^{\mathrm{d}}$ & $-.104^{\mathrm{d}}$ & $-.048^{b}$ \\
\hline Employed & .025 & .021 & -.028 & .001 & -.015 & -.025 & $-.041^{\mathrm{a}}$ & -.010 \\
\hline Male & -.012 & -.001 & -.043 & -.014 & .018 & -.005 & .021 & $-.034^{\mathrm{b}}$ \\
\hline Not Married & .014 & -.013 & -.032 & -.013 & -.006 & -.037 & .002 & .030 \\
\hline Age & -.026 & -.020 & -.019 & -.033 & .000 & .001 & -.033 & -.017 \\
\hline $\begin{array}{l}\text { Rural (smaller town for } \\
\text { KSA) }\end{array}$ & $-.036^{\mathrm{a}}$ & $.092^{\mathrm{d}}$ & $.276^{\mathrm{d}}$ & -.010 & $-.049^{b}$ & .018 & $.051^{\mathrm{b}}$ & $.107^{\mathrm{d}}$ \\
\hline \multicolumn{9}{|c|}{ Religious Identity } \\
\hline Shia vs. Sunni & $-.037^{b}$ & & $-.549^{d}$ & & $-.116^{\mathrm{d}}$ & & $-.038^{\mathrm{a}}$ & $-.154^{\mathrm{d}}$ \\
\hline Druze vs. Sunni & & & & & & & & $-.111^{\mathrm{d}}$ \\
\hline $\begin{array}{c}\text { Muslim (Sect unidentified) } \\
\text { vs. Sunni }\end{array}$ & .004 & & & & $-.233^{\mathrm{d}}$ & & $.051^{\mathrm{b}}$ & -.028 \\
\hline Christian vs. Sunni & $-.083^{\mathrm{d}}$ & -.030 & & $-.154^{\mathrm{d}}$ & & & & $-.118^{\mathrm{d}}$ \\
\hline Other vs. Sunni & $-.129^{\mathrm{d}}$ & & & & & & -.012 & $-.125^{\mathrm{d}}$ \\
\hline
\end{tabular}




\begin{tabular}{|c|c|c|c|c|c|c|c|c|}
\hline \multicolumn{9}{|c|}{ Ethnic Identity } \\
\hline Sindhi vs. Punjabi & $-.077^{\mathrm{d}}$ & & & & & & & \\
\hline Pathan vs. Punjabi & $-.045^{\mathrm{b}}$ & & & & & & & \\
\hline Kashmiri vs. Punjabi & .024 & & & & & & & \\
\hline Other vs. Punjabi/Arab & $-.094^{\mathrm{a}}$ & & & & & $-.038^{\mathrm{a}}$ & & $-.031^{\mathrm{a}}$ \\
\hline $\begin{array}{c}\text { Kurd/Berber ys. } \\
\text { Arab/Kurd vs. Turk }\end{array}$ & & & & & .037 & $-.057^{\mathrm{c}}$ & $-.037^{\mathrm{a}}$ & \\
\hline Palestinian vs. Jordanian & & & & $-.060^{\mathrm{b}}$ & & & & \\
\hline \multicolumn{9}{|c|}{ Religion } \\
\hline Relis & $.111^{\mathrm{d}}$ & .009 & $.139^{\mathrm{d}}$ & $.052^{\mathrm{b}}$ & $.107^{\mathrm{d}}$ & $.080^{\mathrm{d}}$ &. $.082^{\mathrm{d}}$ & $.243^{\mathrm{d}}$ \\
\hline $\begin{array}{r}\text { Trust in } \mathrm{R} \\
\text { Institu }\end{array}$ & $.037^{\mathrm{a}}$ & $.062^{\mathrm{a}}$ & $.092^{\mathrm{d}}$ & $.123^{\mathrm{d}}$ & $.087 \mathrm{c}$ & $.135^{\mathrm{d}}$ & $.092^{\mathrm{d}}$ & $.052^{\mathrm{b}}$ \\
\hline Religious Mor & $.107^{\mathrm{d}}$ & $.084^{\mathrm{d}}$ & $.148^{\mathrm{d}}$ & & $.228^{\mathrm{d}}$ & & .219 & $.285^{\mathrm{d}}$ \\
\hline \multicolumn{9}{|c|}{ Perception \& Values } \\
\hline $\begin{array}{c}\text { Conspiracies against } \\
\text { Muslim }\end{array}$ & $.092^{\mathrm{d}}$ & $.097^{\mathrm{d}}$ & $.098^{\mathrm{d}}$ & $.147^{\mathrm{d}}$ & $.283^{\mathrm{d}}$ & .018 & $.053^{\mathrm{b}}$ & $.099^{\mathrm{d}}$ \\
\hline Xenor & $.032^{\mathrm{a}}$ & $.040^{\mathrm{a}}$ & $.103^{\mathrm{d}}$ & $.083^{\mathrm{d}}$ & -.015 & $.113^{\mathrm{d}}$ & .006 & $.097^{\mathrm{d}}$ \\
\hline Fatalism & $.081^{\mathrm{d}}$ & .035 & $.064^{\mathrm{c}}$ & $.115^{\mathrm{d}}$ & $.175^{\mathrm{d}}$ & $.176^{\mathrm{d}}$ & $.050^{\mathrm{b}}$ & $.067^{\mathrm{d}}$ \\
\hline Liberalism & $-.334^{\mathrm{d}}$ & $-.163^{\mathrm{d}}$ & $-.175^{\mathrm{d}}$ & $-.206^{\mathrm{d}}$ & $-.148^{\mathrm{d}}$ & $-.312^{\mathrm{d}}$ & $-.302^{\mathrm{d}}$ & $-.147^{\mathrm{d}}$ \\
\hline \multirow{4}{*}{ df regression/dfresidual } & $105.07^{\mathrm{d}}$ & $27.25^{\mathrm{d}}$ & $81.32^{\mathrm{d}}$ & $62.33^{\mathrm{d}}$ & $60.63^{d}$ & $77.20^{\mathrm{d}}$ & $78.20^{\mathrm{d}}$ & $128.72^{\mathrm{d}}$ \\
\hline & $3363 / 21$ & $2767 / 14$ & $1494 / 13$ & $2889 / 14$ & $2477 / 17$ & $2475 / 14$ & $2328 / 17$ & $2419 / 19$ \\
\hline & .396 & .121 & .415 & .232 & .294 & .304 & .364 & .503 \\
\hline & $.078^{\mathrm{d}}$ & $.040^{\mathrm{d}}$ & $.034^{\mathrm{d}}$ & $.091^{\mathrm{d}}$ & $.104^{\mathrm{d}}$ & $.141^{\mathrm{d}}$ &. $.074^{\mathrm{b}}$ & $.039^{\mathrm{d}}$ \\
\hline
\end{tabular}

Table 10 Hierarchical Linear Regression Estimates ( $\beta$ ) Prediction of Fundamentalism Model 5

\begin{tabular}{|c|c|c|c|c|c|c|c|c|}
\hline Variable & Pakistan & Egypt & KSA & Jordan & Iraq & Tunisia & Turkey & Lebanon \\
\hline \multicolumn{9}{|c|}{ Demographics } \\
\hline Socioeconomic status & $-.044^{b}$ & $-.115^{\mathrm{d}}$ & $-.054^{\mathrm{b}}$ & $-.118^{\mathrm{d}}$ & $-.073^{\mathrm{d}}$ & $-.126^{\mathrm{d}}$ & $-.096^{\mathrm{d}}$ & $-.035^{\mathrm{a}}$ \\
\hline & .027 & .025 & -.016 & .004 & -.018 & -.023 & $-.041^{\mathrm{a}}$ & .006 \\
\hline & -.006 & -.001 & -.017 & -.010 & .014 & .002 & .022 & -.024 \\
\hline Not Married & .016 & -.009 & -.036 & -.010 & -.007 & -.027 & .004 & .036 \\
\hline Age & -.031 & -.015 & -.040 & -.040 & .004 & -.013 & -.037 & -.025 \\
\hline Rural (smaller town for & $-.044^{b}$ & $.086^{\mathrm{d}}$ & $.310^{\mathrm{d}}$ & -.011 & $-.042^{\mathrm{a}}$ & .016 & $.049^{\mathrm{b}}$ & $.102^{\mathrm{d}}$ \\
\hline \multicolumn{9}{|c|}{ Religious Identity } \\
\hline $\begin{array}{l}\text { Shia vs. Sunni } \\
\text { Druze vs. Sunni }\end{array}$ & $-.038^{b}$ & & $-.561^{\mathrm{d}}$ & & $-.115^{\mathrm{d}}$ & & $-.037^{\mathrm{a}}$ & $\begin{array}{l}-.160^{\mathrm{d}} \\
-.108^{\mathrm{d}}\end{array}$ \\
\hline Muslim (Sect unidentified) vs & -.003 & & & & $-.226^{\mathrm{d}}$ & & $.051^{\mathrm{b}}$ & -.024 \\
\hline Christian vs. Sunni & $-.084^{\mathrm{d}}$ & -.033 & & $-.154^{\mathrm{d}}$ & & & & $-.111^{\mathrm{d}}$ \\
\hline Other vs. Sunni & $-.133^{\mathrm{d}}$ & & & & & & -.011 & $-.119^{\mathrm{d}}$ \\
\hline
\end{tabular}

Ethnic Identity

\begin{tabular}{l|l} 
Sindhi vs. Punjabi & $-.076^{\mathrm{d}}$ \\
Pathan vs. Punjabi & $-.050^{\mathrm{b}}$
\end{tabular} 


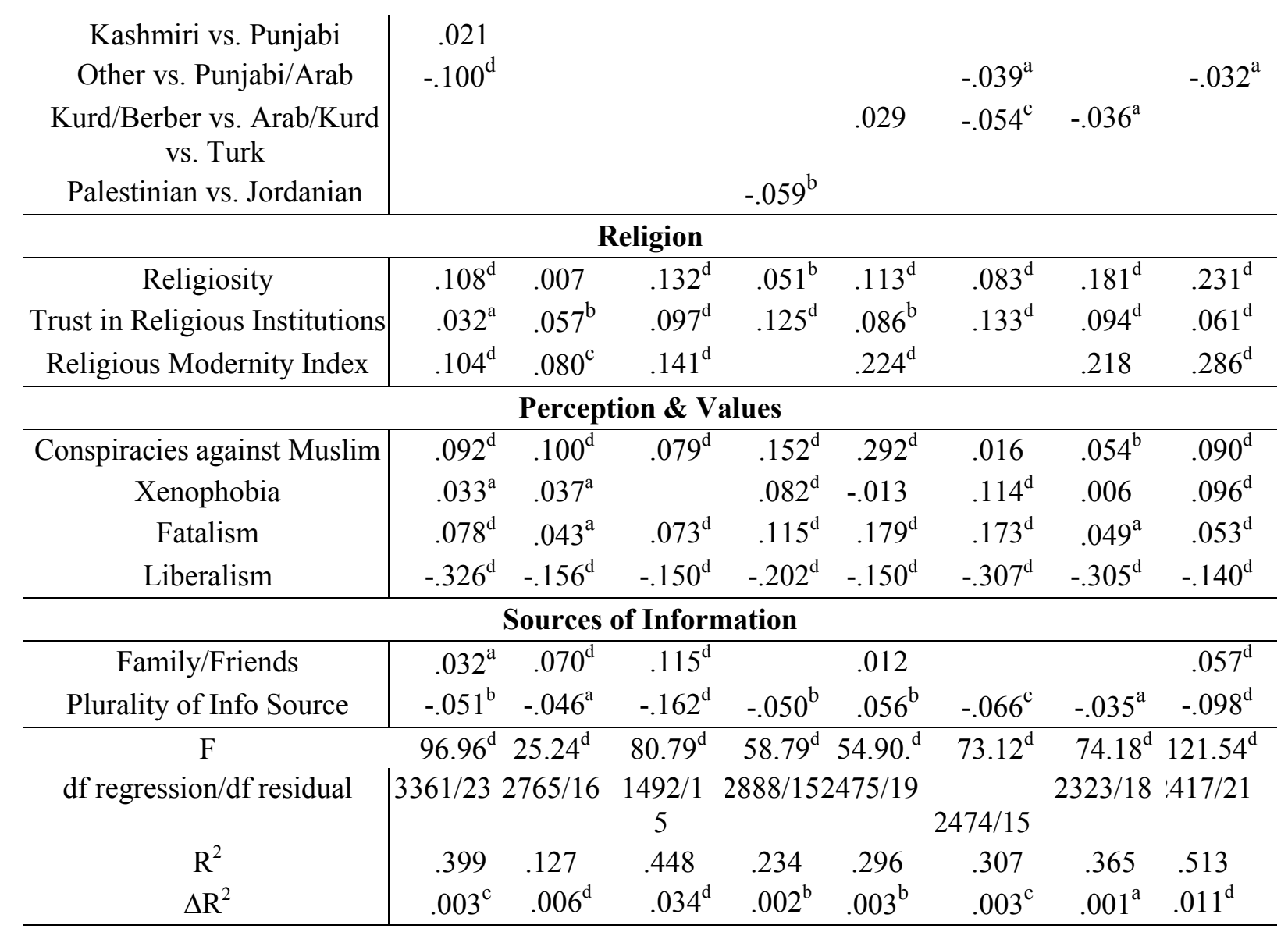

${ }^{\mathrm{a}} p<.05 \quad{ }^{\mathrm{b}} p<.01{ }^{\mathrm{c}} p<.001{ }^{\mathrm{d}} p<.0001 \quad \mathrm{KSA}=$ Kingdom of Saudi Arabia 